\title{
Plant and Animal Resources and Ecological Condition of the Hanging Woman Basin in Big Horn County, Montana and Sheridan County Wyoming
}

\author{
Prepared for: \\ Padlock Ranch \\ and
}

The Bureau of Land Management

By:

John C. Carlson and Stephen V. Cooper

Montana Natural Heritage Program

Natural Resource Information System

Montana State Library

February 2003

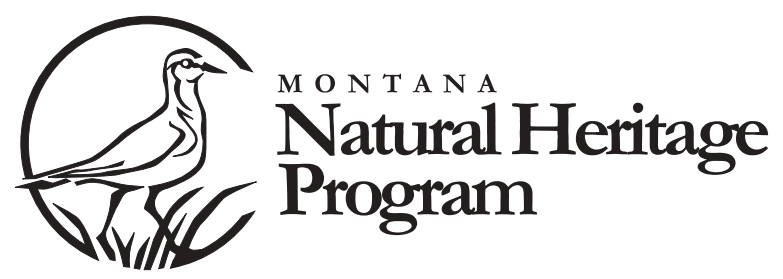




\section{Plant and Animal Resources and Ecological Condition of the Hanging Woman Basin in Big Horn County, Montana and Sheridan County Wyoming}

by

John C. Carlson and Stephen V. Cooper

Montana Natural Heritage Program

1515 East Sixth Avenue

Helena, Montana 596201800
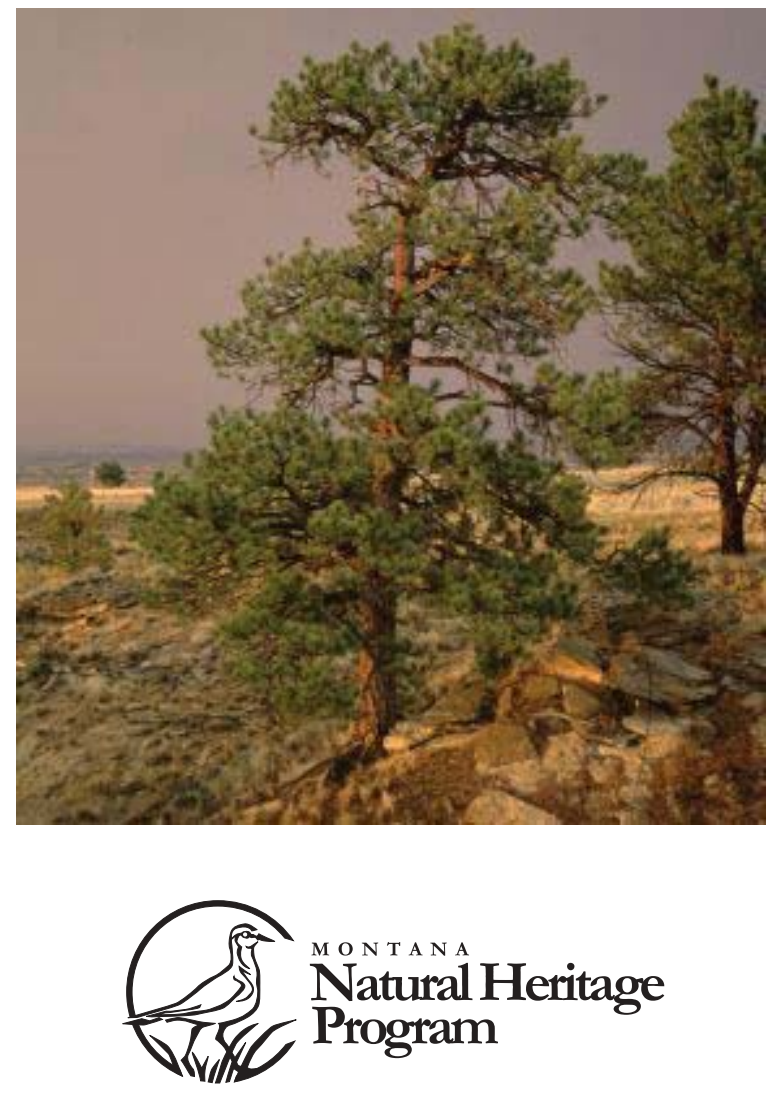

(c) 2003 Montana Natural Heritage Program

P.O. Box $201800 \bullet 1515$ East Sixth Avenue • Helena, MT 59620-1800 • 406-444-3009 
This document should be cited as follows:

J.C. Carlson and S. V. Cooper. 2003. Plant and Animal Resources and Ecological Condition of the Forks Ranch Unit of the Padlock Ranch, Big Horn County, Montana and Sheridan County, Wyoming. Report to the Padlock Ranch and the Montana BLM. Montana Natural Heritage Program, Helena. 27 pp. plus appendices. 


\section{ACKnOWledgments}

We would like to thank John Heyneman for his introduction to the Forks Ranch and the ranch staff for their hospitality, food and tire repair skills when we visited the ranch. Roxanne Falise at Montana BLM and Dave Mehlman at TNC provided help with this project. We would also like to thank the Wyoming Natural Diversity Database for providing data for the Wyoming portion side of the Hanging Woman Basin. Padlock Ranch and the Bureau of Land Management provided funding for this project. Sue Crispin and Coburn Currier provided invaluable editing assistance. Coburn Currier also produced this report and his diligent efforts helped make it look right. 


\section{EXeCuTIVe Summary}

The biological resources of southeastern Montana are not well documented. Recent proposals to develop large portions of this landscape for the production of coal-bed methane have focused attention on the potential effects of such development on the region's wildlife, vegetation, and ecosystems. This report provides an initial overview of biological resources within the Hanging Woman Creek Basin of southeastern Montana and, in general, the middle portion of the Tongue River Basin in Montana and Wyoming.

This overview focused on animal and plant Species of Concern and plant communities, but also included other animal species observed or expected in the Basin. We conducted three brief field surveys, focused on the Forks Ranch Unit of the Padlock, and assembled previously collected data from the Montana Natural Heritage Program and the Wyoming Natural Diversity Database, as well as data from other sources. Though examples of all habitats were included in the survey, an exhaustive search of appropriate habitat for particular sensitive species was not conducted.

The most important animal species present within the Hanging Woman Basin from a conservation perspective are the Black-tailed Prairie Dog and the Greater Sage Grouse. Other animal Species of Concern documented in or near the basin include Northern Grasshopper Mouse (Onychomys leucogaster), Merriam's shrew (Sorex merriami), Burrowing Owls, Greater Short-horned Lizards (Phrynosoma hernandesi), Northern Leopard Frog (Rana pipiens), Great Plains Toad (Bufo cognatus) and Plains Spadefoot (Spea bombifrons). Extensive sage habitats in the Hanging Woman Basin potentially provide habitat for a number of sage obligate bird species, including Sage Thrasher (Oreoscoptes montanus), Sage Sparrow (Amphispiza belli), Ferruginous Hawk (Buteo regalis), Brewer's Sparrow (Spizella breweri), Lark Bunting (Calamospiza melanocorys), and Loggerhead Shrike (Lanius ludovicianus). The Milk Snake (Lampropeltis triangulum), a species of concern for both Montana and Wyoming, potentially occurs along sandstone outcrops, ridges and escarpments associated with Ponderosa pine communities.

We documented 13 plant associations on the ranch, though approximately 73 community types are known to occur in this ecoregional Section. Greater community diversity almost certainly exists in the basin, particularly in wetland or riparian areas and badlands, which could not be adequately inventoried in this brief assessment. Three plant taxa of global significance have been documented in this basin or the Upper Tongue River drainage. Barr's milkvetch (Astragalus barrii) and Wooly twinpod (Physaria didymocarpa var. lanata) tend to occupy high knobs and outcrops, while Nuttall's desert-parsley (Lomatium nuttallii) grows on mid- to lower-slopes, especially along drainages. 


\section{Table of Contents}

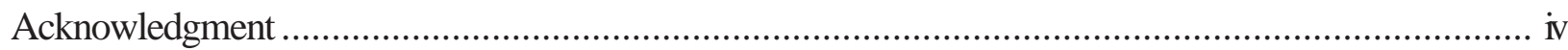

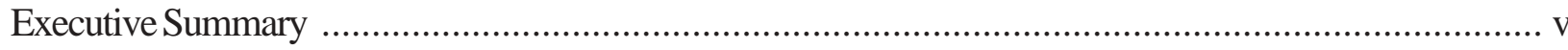

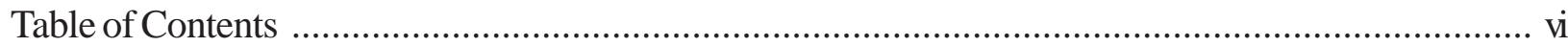

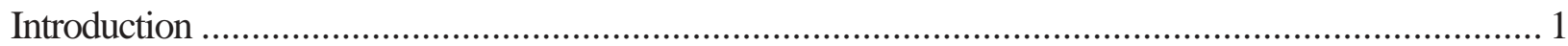

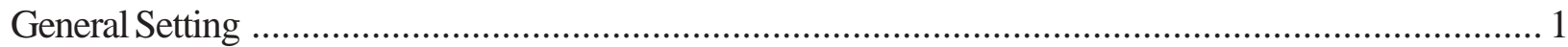

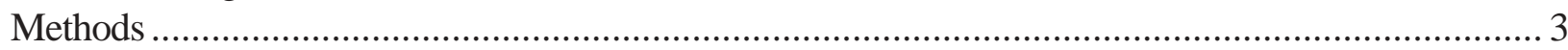

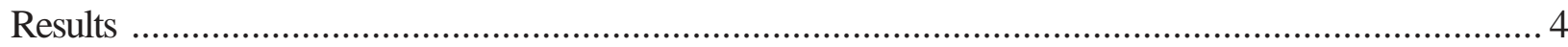

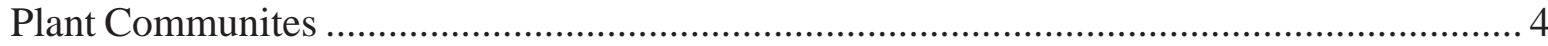

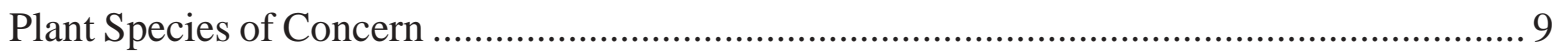

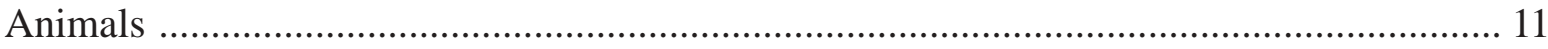

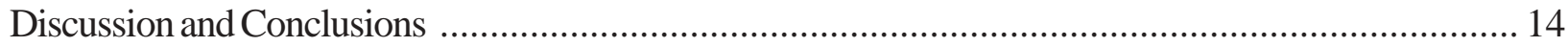

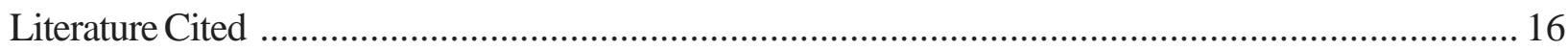

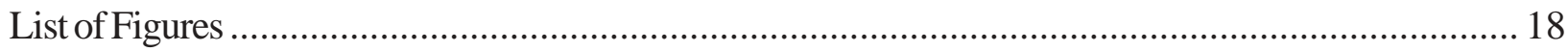

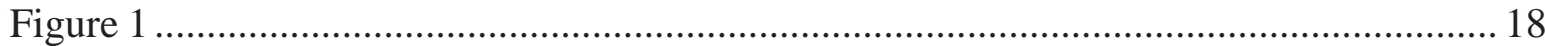

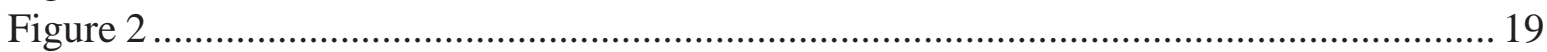

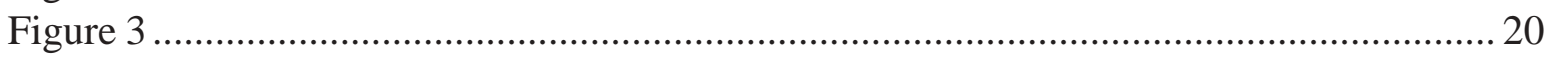

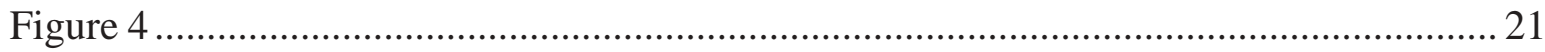

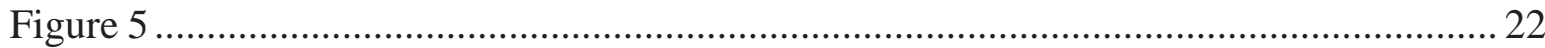

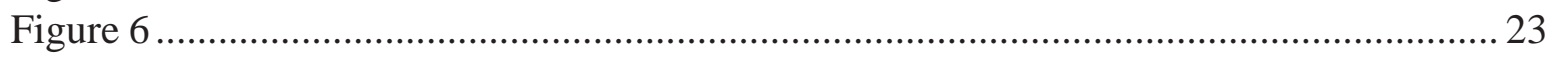

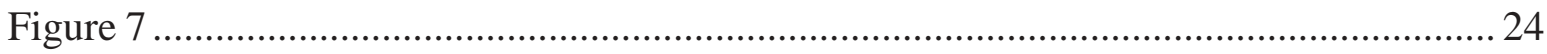

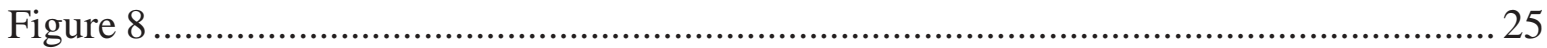

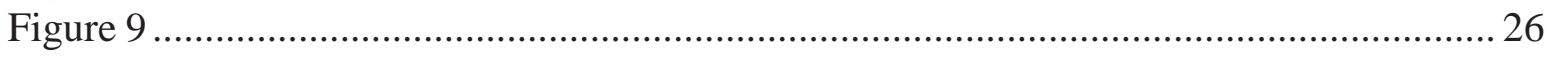

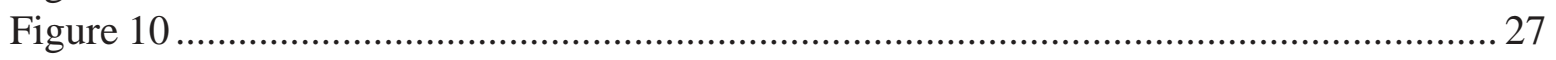

List of Appendicies

Appendix 1. Global/State Rank Definitions

Appendix 2. Animal Species in the Hanging Woman Basin.

Appendix 3. Plant Species of Concern Documented or Potentially Occurring in the Hanging Woman Basin.

Appendix 4. Potential Plant Associations 


\section{INTRODUCTION}

The biological resources of southeastern Montana are not well documented. Recent proposals to develop large portions of this landscape for the production of coal-bed methane (CBM) have focused attention on the potential effects of CBM development on the region's wildlife, vegetation, and ecosystems. The first step in answering these questions is to assemble information on the biological resources that currently exist in this landscape.

This report provides an initial overview of biological resources within the Hanging Woman Creek Basin of southeastern Montana and, in general, the middle portion of the Tongue River Basin in Montana and Wyoming. This area was selected at the request of, and with financial support from, the Padlock Ranch, Forks Unit to assist Ranch managers in working with industry to minimize impacts of energy development on wildlife and vegetation. The Bureau of Land Management also supported the work, to help build a stronger information base of biological resources in this poorly documented area of the state.

Although much of the report is focused on animal and plant species of concern, we also documented plant communities and other animal species observed and expected to occur in the Basin. We conducted three brief field surveys on the Ranch, and assembled previously collected data from the Montana Natural Heritage Program and the Wyoming Natural Diversity Database, as well as data from other sources, to produce this overview. Based on this information, we also provide a preliminary assessment of the current status of the plants, plant communities and animals within this landscape, and some observations about management of those resources.

\section{General Setting}

The Hanging Woman Basin is situated in predominantly gently rolling prairie located about 50 and 18 air miles respectively from Sheridan, Wyoming and Decker, Montana. Though the occasional hillock, minor escarpment and butte are present and some areas are highly dissected by dendritic drainages, the overall impression is of a gently undulating tableland with shallowly entrenched tributaries to the main drainage, Hanging Woman Creek. The major drainages of this basin include the West, Middle and North Prongs of Hanging Woman Creek, Trail, Deep, Waddle and Seventysix Creeks. Elevations range from just over 3,500 feet along the northern portion of Hanging Woman Creek to slightly less than 4,100 feet on the apex of several of the buttes (Figure 1). Hanging Woman Creek joins the Tongue River near the town of Birney, Montana.

Bedrock and surficial geology accords with that of much of southcentral Montana and northcentral Wyoming. With the exception of Quaternary alluvium deposited along the lower reaches of Hanging Woman Creek, parent material is predominantly sedimentary rock, mudstones and clay shales of the Cretaceous age Fort Union Formation and sandstones of the Wasatch Formation. Sandy soils generally occur in the uppermost positions in the local landscape associated with a more weathering resistant caprock; also occurring to a minor extent in elevated positions are thermally altered shales and mudstones (forming clinker and scoria). Soils of mid to lower slopes are characteristically loams (mostly silt loams), whereas those of the toeslopes, terraces and bottoms are silty, often with a high percentage of clay. 
The area's climate is continental with hot summers, cold winters and the bulk of precipitation in the late spring and early summer. The Otter 9SSW Station (MT) at 4,060 feet elevation (closest to and representing the highest portions of the Fork Ranch Unit) receives an average of $18.9 \mathrm{in}$. of precipitation and has mean January and July temperatures of $21.5 \infty$ and 72.200 respectively (based on 1961-1990 period of record). The Otter Station, for the period of April - June, receives on average more than 8 inches of precipitation, or $42 \%$ of the annual amount. To the west of the Forks Ranch at the Decker $1 \mathrm{E}$ Station (3,500 feet and representing a modal elevation for the ranch), precipitation for April - June is just over 5.5 inches, or $46 \%$ of the annual average of 12.15 inches. Precipitation appears to increase rapidly with elevation in this part of the Powder River Basin, based on an expected 12 to 14 inches annually for the lower portions of the Fork Ranch Unit (down to 3,500 feet) compared with more than 18 inches (USDA-NRCS 1999) expected for the upper elevations (only 500 feet higher).

Climate drives community composition and patterning, however weather of the recent past (last several years to present) determines community productivity and may cause compositional shifts or failure of some species to flower or even appear. For at least two years $(2000,2001)$ prior to our sampling, a drought has plagued this portion of Montana/Wyoming and continued well into the summer of 2002. For the critical precipitation period of April-June (especially critical to cool-season grasses), the last three years were 2.17, 3.66, and 3.42 inches below normal, an average decrease of 55\%. This ongoing and deep drought has severely reduced forage production and made inventory of plant populations and communities more difficult. The combination of drought-stressed communities and livestock grazing has also resulted in extensively depleted range and made it difficult to evaluate the ecological status of communities.

Due to the relatively restricted climatic gradient, and the narrow range and consistency of topographic relief and parent materials, the vegetation on the Ranch is characterized by extensive areas of relatively common community types. It is conceivable that, in the absence of disturbance/treatments, the entire Forks Ranch would be covered by Wyoming big sagebrush (Artemisia tridentata ssp. wyomingensis)-dominated shrubland or shrub herbaceous plant associations. Exceptions would be riparian hardwood stringers, alluvial bottomlands with or without the influence of alkaline soils, sandstone outcrops with xeric ponderosa pine (Pinus ponderosa) woodlands, and scoria exposures with a sparse, depauperate vegetative cover. Where Wyoming big sagebrush has been disturbed (burned or ìconvertedî by other means), mesic grasslands persist until the sagebrush can reestablish dominance. Black-tailed prairie dog (Cynomys ludovicianus) colonies also constitute a significant disturbance, creating grass-dominated areas that represent an earlier successional stage in the progression to A. tridentata ssp. wyomingensis dominance.

Animal distributions in the Basin would be expected to follow vegetation conditions in the absence of disturbances, as noted above. Sage obligate and sage associated species would be expected through out the sagebrush habitat type, and a number of species associated with prairie dog towns would be present. The populations of these prairie dog associated species would depend on the size and extent of the prairie dog colonies, which may have been extensive prior to control efforts. Much of the animal diversity would have been centered along the riparian hardwood stringers where the increased structural complexity provides habitat for a wider range of species. 


\section{Methods}

Field procedures were designed to inventory for both plant communities and sensitive plant and animal species; given that only four field days were available for the plant surveys as well as the animal surveys, a balance was struck between intensive survey for particular species and a broad-brush assessment of the animal and plant communities. Sampling was focused on the Forks Ranch Unit, and was conducted as an informal gradsect approach (Austin and Heyligers 1989), with travel routes chosen to include the full range of abiotic parameters; these same routes were also used for sensitive plant and animal species inventories. Though examples of all habitats were included in the survey, an exhaustive search of appropriate habitat for particular sensitive species was not conducted. Plant and plant community surveys were conducted by Stephan V. Cooper between June 12 and 14, 2002. Animal surveys were conducted by John C. Carlson from July 15 to July 17, 2002. Additional small mammal trapping was conducted on the Padlock Ranch from August 21 to August 23, 2002 by John C. Carlson as part of a larger statewide effort funded by Montana Fish, Wildlife, and Parks.

Prior to conducting fieldwork, we prepared a ìsearch listî of plant (Appendix 3) and animal (Appendix 2) species and their habitats to use in planning and conducting field surveys. It included Montana and Wyoming plant and animal species of concern that had been previously documented from Big Horn County, MT or Sheridan County, WY or from adjoining counties, consistent with current species of concern lists for Montana (Heidel 1999, Carlson 2001) and Wyoming (Wyoming Natural Diversity Database 2002). We documented all locations of species of concern encountered during our surveys.

We also selected 33 plant associations that could occur in the Forks Ranch Unit (Appendix 4) as search targets from a list of plant communities compiled during a rapid ecological assessment in the Powder River Basin Section of the Great Plains-Palouse Dry Steppe Province (331G of Bailey1995, Martin et al. 1998). When we encountered plant associations ranked G3 or S3 and higher, we recorded species composition and cover, at least for the first occurrence noted.

For common communities, ranked G4 and lower, we noted their occurrence and made some observations on their position in the landscape and areal extent. It should be noted that no definitive plant association classification has been published for this local and thus the communities inventoried in this study were compared to those described in EcoArt (NatureServe 2002) or the classifications of greatest geographic and ecologic propinquity (DeVelice et al. 1995; DeVelice and Lesica 1993; Vanderhorst et al. 1998). Sampling sites for communities are depicted in Figure 1.

Small mammal surveys consisted of four trap lines with ten trap stations each. At each station one snap trap and one Sherman live trap were deployed. Snap traps were baited with peanut butter and Sherman traps were baited with an oatmeal/commercial birdseed mixture. In addition two pit trap arrays were deployed near two of the trap lines. Each array consisted of four plastic cup pits traps at the center and at each end of three masonite fences radiating from a central point. 


\section{Results}

\section{Plant Communities}

\section{SHRUBLANDS:}

By far the greatest portion of the Fork Ranch Unit is potentially dominated by Wyoming big sagebrush (Artemisia tridentata ssp. wyomingensis) (Figure 6); only restricted habitats such as riparian bottoms, ridgeline outcrops and sandy or extremely eroded outcrops are not likely to be Wyoming big sagebrush dominated. The extensive grasslands found over slopes and flats is attributable to past burning of the range, either as a sagebrush ìcontrolî measure or as wildfire. Anecdotal evidence is beginning to accumulate to show that response to disturbance varies significantly among subspecies of big sagebrush and that Wyoming big sagebrush is very slow to revegetate disturbed areas, regardless of treatment type. This response has significant implications for managing not only for livestock but also for a healthy and diverse ecosystem.

The only other shrub of any consequence is black greasewood (Sarcobatus vermiculatus), which is restricted to alkaline or salt-affected bottomlands (Figure 9). and also rarely occurs on sideslopes where appropriate soil conditions exist. Also associated with bottomlands is silver sage (Artemisia cana ssp. cana) but, it favors substrates that are not salt-affected or alkaline. Very small patches of Gardner's saltbush (Atriplex gardneri) were found on highly erosive clay outcrops; associated species were few and inconsistently present from patch to patch, thus no particular plant association could be identified for these sites. Fragrent sumac / bluebunch wheatgrass (Rhus trilobata / Pseudoroegneria spicata) was also noted as fragmentary occurrences on eroding slope shoulders of sandy knolls and escarpments. Prairie junegrass (Koeleria macrantha) canopy cover is higher than would be expected and has probably increased as a result of intensive grazing pressure placed on preferred species.

\section{Plant Association Descriptions}

\section{Artemisia cana ssp. cana / Pascopyrum smithii (formerly Elymus smithii) Shrub Herbaceous Plant Association:}

The first terrace up from streams and coalesced fans support this community. The cover of A. cana ssp cana is generally low, between 5 and $20 \%$, not technically enough to qualify sites as true shrublands (according to NVCS); the only other shrub occurring here is Sarcobatus vermiculatus. The undergrowth is almost exclusively comprised of graminoids, among which $P$. smithii and the exotic Poa pratensis are usually dominant (cover between 30 and 70\%), and Koeleria macrantha, Poa secunda, and Nassella viridula (formerly Stipa viridula) are consistently represented. Though seldom present with greater than $5-10 \%$ cover under favorable conditions, the fact that Nassella viridula is present in mere trace amounts may be indicative of past intensive grazing.

\section{Artemisia cana ssp. cana / Carex inops ssp. heliophila Shrub Herbaceous Plant Association:}

The lone occurrence of this association on the Forks Unit comprises a small recently burned patch and thus represents a relatively early successional stage in a burned community (ostensibly of the same name, though its composition might have been somewhat different). A. cana ssp. cana is well known to stump-sprout and is not confined to alluvial positions as this association evidences by it hillslope position on fine sands. In this stand A. cana ssp. cana has stump sprouted and approaches $20 \%$ cover. Other 
herbs, whose presence is generally tied to sandy substrates, include Pediomelum argophyllum (formerly Psoralea argophylla), Calamovilfa longifolia, and Oryzopsis hymenoides. Poa secunda and Festuca idahoensis exhibit covers in excess of $10 \%$. To date this community has been reported only for Montana, but this occurrence would indicate appropriate habitats in Wyoming also support it.

\section{Artemisia tridentata ssp. wyomingensis / Pseudoroegneria spicata (formerly Agropyron spicatum or Elymus spicata) Shrub Herbaceous Plant Association:}

Generally steep slopes with moderately coarse-textured soils (e.g. sandy loams) support sparse stands (canopy cover 10-20\%) of A. tridentata ssp. wyomingensis with an undergrowth dominated by low coverages of $P$. spicata and Koeleria macrantha and Carex filifolia; areas transitional to finertextured soils support significant amounts of Pascopyrum smithii (where the cover of P. smithii becomes sufficient to indicate a type with that name has not been formally established). The only exotic of note, Bromus tectorum, is present here in low to moderate cover, generally less than $20 \%$. Associated shrubs reflecting the coarse soils include Rhus trilobata, Yucca glauca, Artemisia frigida, Gutierrezia sarothrae, and Ericameria nauseosa (formerly Chrysothamnus nauseosus). The forb component is both species depauperate and low in aggregate canopy cover; common species include Phlox hoodii, Lomatium cous, Erigeron pumilus, and Allium textile. [In the National Vegetation Classification Standard the designation iShrub Herbaceousî is used to denoted vegetation types wherein the shrub component has less than $25 \%$ cover, which is clearly the case with this relatively xeric big sagebrush type]

Artemisia tridentata ssp. wyomingensis / Pascopyrum smithii (formerly Agropyron smithii or Elymus smithii) Shrub Herbaceous Plant Association:

Most of the Fork Ranch would support various permutations of this association had not various disturbances, predominantly burning, occurred in the past. As the most common plant association on the Fork Ranch, this association is capable of dominating from just above the riparian zone (and is found on the first terrace up from streams often considered part of the riparian) to the top, or sometimes only the shoulder, of ridges and hills. It is associated with medium-to fine-textured soils (loams to silt and clay loams) derived from the sedimentary Fort Union Formation. A. tridentata ssp. wyomingensis cover is generally greater here than in the A. tridentate ssp. wyomingensis / P. spicata P. A., ranging from about 10 to $30 \%$. Besides the diagnostic $P$. smithii (whose cover ranged from 20 to $60 \%$ and would be higher in a non-drought year), other native graminoids consistently present include Poa secunda, Nassella viridula (= Stipa viridula), and Koeleria macrantha. The fact that Nassella is present in such low cover, even on the sites most favorable to its development (toeslopes, swales) may be explained by past intensive grazing (it is highly palatable) or the ongoing drought or a combination of these two factors. Poa pratensis is a major increaser species on the more mesic portion of this association. Bromus tectorum has also responded to disturbance but does not seem to pose a threat to native populations except where disturbance is intensive and ongoing. Forb cover seldom exceeds 5\% and commonly includes Sphaeralcea coccinea, Comandra umbellata, Crepis spp. and Astragalus agrestis.

\section{Sarcobatus vermiculatus / Pascopyrum smithii (formerly Elymus or Agropyron smithii) Shrub Herbaceous Plant Association: \\ This community is associated with alluvial terrace deposits derived from shale or other fine-grained sedimentary material and are mostly small to large patch in extent. All the examples of this type}


examined on the ranch had extremely fine textured, high in clay soils with gap distance of the shrink swell cracks approaching 1.5 inches. We speculate that for a portion of the year soils, due to the water-perching potential of the heavy-textured soils, are saturated to a depth tapped by $S$.

vermiculatus. Of the sites examined on the Fork Ranch none possessed hydric soils, though several sites showed traces of salt efflorescence indicating alkaline conditions. The cover of Sarcobatus, the only shrub noted on these sites, ranges from 5 to $20 \%$ and the undergrowth is very depauperate. We noted a considerable variation in the cover of Pascopyrum, from less than $5 \%$ to more than $70 \%$. These sites are easily accessible to livestock and presumably some of this variation in graminoid cover is explained by differing grazing pressures, yet some may be due to the alkalinity of the soil. Other grasses consistently present are Distichlis spicata and Poa juncifolia (now termed P. secunda but, we cite the older synonomy, $P$ juncifolia, because this taxa is associated with bottomland habitats and $P$. secunda, as currently and broadly defined, is generally not).

\section{Forests AND WoOdLANDS:}

The Hanging Woman Basin receives insufficient rainfall to support more than a woodland condition on the uplands, where ponderosa pine (Pinus ponderosa) and Rocky Mountain juniper (Juniperus scopulorum) are the only trees present (Figure 10). Canopy cover of the tree layer seldom exceeds $50 \%$ and generally ranges from 10 to $35 \%$, which would place many of these communities below the cutoff for woodland (25\%) and in the savanna structure category. Hardwood forests are extremely limited on the Ranch, with narrow riparian stringers dominated by box elder (Acer negundo); wooded riparian areas were incompletely inventoried and may support stands wherein plains cottonwood (Populus deltoides) is a component or even dominant.

\section{Plant Association Descriptions}

\section{Pinus ponderosa / Pseudoroegneria spicata (formerly Agropyron spicatum or Elymus spicatus) Woodland Plant Association:}

This community is found as small, open stands on sandstone outcrops or where sandstone colluvium has mixed with finer textured parent material. Usually stands are associated with warmer exposures of west to south-facing slopes; they also occur on flat to undulating benchlands at the crest of ridges and escarpments. Mature canopy height of $P$. ponderosa does not much exceed 40 feet and Juniperus scopulorum is more of a multistemmed shrub less than 10-12 ft. in height. The undergrowth may have very scattered Yucca glauca and Rhus trilobata, two shrubs often associated with sandy soils. We observed burned areas that had experienced a high degree of $P$. ponderos $a$ mortality to regenerate to Artemisia tridentata ssp. wyomingensis before the tree component is reestablished. However, seldom was A. tridentata a component of older, or even younger, P. ponderosa stands. These observations may point to the protracted nature of succession on these xeric sites (Figure 7). Pinus ponderosa has been observed to establish preferentially on sites with nurse shrubs (e.g. A. tridentata) however, a ratelimiting step in this process is the establishment of $A$. tridentata, which may require 20 to 30 years to generate significant numbers of individuals with mature crowns (affording protection). Pseudoroegneria spicata is the diagnostic and dominant herbaceous species (canopy cover seldom exceeding 20\%) with Carex filifolia and Oryzopsis hymenoides consistently present with low cover values. Some commonly occurring forbs include Astragalus agrestis, Pediomelum argophyllum (formerly Psoralea argophylla), Crepis acuminata, Cirsium spp., Linum lewisii and Antennaria parvifolia. Most of the 
stands of the visited stands of this associated were in good condition with relatively few exotics in the undergrowth (low coverages of Bromus tectorum).

\section{Pinus ponderosa / Festuca idahoensis Woodland Plant Association:}

This association is represented by small stands, often constituting a mere downslope fringe to $P$. ponderosa / P spicatum stands; it is associated with more mesic positions than P. ponderosa $/ P$. spicata, such as north or east-facing slopes but holds in common with the more prevalent forest association an affinity for sandy substrates (which occur near the crest of ridge systems). Scattered shrubs of Rhus trilobata and Artemisia frigida occur in the undergrowth. The graminoid component is like that of $P$. ponderosa / P. spicata but with Festuca idahoensis having at least 5\% canopy cover; Carex inops ssp. heliophila may be present in low coverages. We took this approach to recognizing the type because often the cover of $P$. spicata was appreciable or at least approaching, or even exceeding, that of $F$. idahoensis, a condition apparently not encountered by Hansen and Hoffman (1988) and not well accommodated by their key. The forb component is like that of $P$. ponderosa $/ P$. spicata but, has in addition, some more mesic species e.g. Geum triflorum, Potentilla arguta, and Potentilla gracilis.

\section{Pinus ponderosa / Carex inops ssp. heliophila Woodland:}

This association was not found but is strongly suspected to occur in a very fragmentary way; this prediction is based on observing this community in adjacent landscapes immediately north and east of the study area.

\section{Acer negundo / Prunus virginiana Forest Plant Association:}

Only one small and poor quality stand of this association was examined, though other hardwood stands were spotted with binoculars and appeared to be in the same landscape position (as the one examined), secondary stream corridors and cool toeslopes near or at the heads of drainages. The inventoried site had been severely hummocked by early season cattle use. A highly variable canopy cover of Acer negundo approximately 30 feet tall straddled an intermittent stream course. The non-palatable shrub component of Symphoricarpos occidentalis and Rosa woodsii was abundant whereas the more palatable shrubs Prunus virginiana and Salix spp. were severely browsed and had less cover. The native forbs and graminoids have been negatively impacted by domestic stock to the extent that composition could not be determined (remnant of Maianthemum stellatum was noted) and the exotics and native increasers such as Poa pratensis, Arctium spp., Galium aparine, Taraxacum officinalis, and Achillea millifolium. It appeared (scanning with binoculars) that none of the riparian areas had been fenced to control cattle or wild ungulate browsing pressure and consequently it can be expected that degradation of these areas will be the norm.

\section{Grasslands and SParse Vegetation Types:}

We speculate that in the absence of disturbance nearly the whole of the Forks Ranch would be supporting shrubland communities wherein the major shrub component is Wyoming big sagebrush (Artemisia tridentata ssp. wyomingensis). Because disturbance is both a natural (principally via wildfire) and man-imposed process of this landscape and because there are some azonal soils embedded in the landscape there are also flourishing grassland types (Figure 8). 


\section{Plant Association Descriptions}

\section{Calamovilfa longifolia $\tilde{n}$ Carex inops ssp. heliophila Herbaceous Vegetation Plant Association:}

This association occurs as small patches or linear extensions on north or east-facing slopes having fine sandy soils. Warmer slopes with comparably sandy soils would have a dominant component of Pseudoroegneria spicata. There are indications that, in part, this community is seral to Pinus ponderosa, but the rate of succession is very slow in this dry environment. A variable mix of Calamovilfa longifolia and Carex inops dominate these sites with Schizachyrium scoparium having appreciable cover on unstable or recently stabilized sites. Other graminoids consistently present include Koeleria macrantha, Festuca idahoensis, Hesperostipa comata (formerly Stipa comata) and Poa secunda. On at least one north-slope site $F$. idahoensis had cover in excess of $5 \%$, indicative of relatively mesic conditions, but we classified the site to this type based on the fact that soils were sandy and Calamovilfa was dominant or an important component. Artemisia cana, A. frigida, and Rosa woodsii are consistently present, but their aggregate cover does not $5 \%$; A. tridentata ssp. wyomingensis is conspicuously absent from these sites. Forbs regularly present included Antennaria parviflora, Pediomelum argophyllum (formerly Psoralea argophylla), Cerastium arvense and Opuntia polyacantha.

\section{Distichlis spicata Herbaceous Vegetation Plant Association:}

This is a minor wetland type occurring as small patches, usually linear in form, in saline or alkali-affected drainage margins, basins or swales. It usually gives way to Pascopyrum smithii-dominated sites having better drainage and/or which are less salt-affected.

\section{Pascopyrum smithii (formerly Elymus smithii or Agropyron smithii) ñ Poa secunda (formerly P. sandbergii) Herbaceous Vegetation Plant Association:}

This community, the most common grassland community on the Forks Ranch, is quite extensive as a seral community due in large part to the ìcontrolî of Wyoming big sagebrush; it also in part occupies sites where big sagebrush might not be expected (mesic sites in drainage bottoms). It occurs on finetextured soils of stream terraces, with soils so heavy that drying cracks are more than an inch wide; it also is found on all but the most xeric of upland sites (such as south facing slopes shoulders, and even here it may occur as a depauperate community). It is dominated by $P$. smithii, though in some cases where grazing has been intensive (or perhaps just its intrinsic expression under drought conditions) $P o a$ secunda has nearly equivalent cover values. In other expressions of the type Koeleria macrantha has greater cover than $P$. secunda and only under exceptionally heavy grazing does Koeleria become dominant over $P$. smithii (K. macrantha is generally not used as an indicator species of natural conditions because it is the most ubiquitous of cespitose grasses and relatively unpalatable to domestic stock or wild ungulates and thus an increaser under grazing). Shrubs and subshrubs were present in only trace amounts and fringed sage (Artemisia frigida) was the only species occurring with greater than $50 \%$ constancy. The relatively depauperate forb component may be explained by many of the sites examined having experienced fire in the recent to distant past (presuming forbs to be negatively impacted by the fires) and the stress of an ongoing drought. The most common forbs were exotics, Taraxacum officinalis and Tragopogon dubius. Another explanation of forb scarcity could be historic sheep grazing but not knowing ranch history this reason is purely speculative. The interaction of all three factors to produce an exacerbated condition is not unlikely. 


\section{Pseudoroegneria spicata / Cushion Plant Sparse Vegetation:}

Ostensibly this is a relatively rare community type (G3) that has been described only from the Tendoy Mountains of western Montana and Big Horn and Custer Counties of eastern Montana (DeVelice and Lesica 1993) and possibly extending into Wyoming's portion of the Bighorn Canyon NRA(as ìwindswept plateau grasslandî Knight et al. 1987). It is found as small patches on ìbadlandsî terrain characterized by thin and eroding soils; site severity is often exacerbated by the impact of southwesterly winds on what are the most projecting landforms in local landscapes. On the Forks Ranch, this type of terrain is restricted to the very tops and shoulders of ridges and mini-buttes. The vegetation is very sparse, usually with less than $15 \%$ cover and plants often are pedicelled due to the natural erosivity of the substrates; in some cases the substrate appeared to be clinker and in other cases a sedimentary deposit was indicated. Pseudoroegneria spicata is the most abundant species but it cover does not exceed $10 \%$. Very dwarfed forms (not exceeding $2 \mathrm{dm}$ ) of Artemisia tridentata ssp. wyomingensis and Ericameria nauseosus (formerly Chrysothamnus nauseosus) occur as scattered individuals. The forb component is depauperate in cover and composition, characterized by the cushion forming Eriogonum brevicaule and other cushion formers such as Musineon divaricatum, Lomatium spp., Hymenoxys acaulis, and Phlox hoodii. This community its very close in composition, structure and site parameters to the Pseudoroegneria spicata / Cushion Plant community described from the Pryor Mountain area (DeVelice and Lesica 1993).

\section{Pseudoroegneria spicata (formerly Agropyron spicatum or Elymus spicatus)ñ Pascopyrum smithii (formerly Elymus smithii) Herbaceous Vegetation Plant Association:}

This is a common grassland community across the Northern Great Plains and foothills of the U.S. portion of the Rocky Mountains. On the Forks Ranch it has a limited distribution, usually occurring on loamy soils on the upper third of slopes with warm aspects and was always associated with sagebrush sites that has burned in the recent past. Pseudoroegneria spicatum has responded well post-fire but Pascopyrum smithii has not regained the cover it ostensibly had prior to being burned (compared to $P$. smithii cover in adjacent $A$. tridentata ssp. wyomingensis-dominated stands). Hesperostipa comata (formerly Stipa comata) and Koeleria macrantha (formerly K. cristata) are consistently present in low cover, unless grazing has been intensive, in which case both are increasers. Annual bromes (Bromus tectorum, B. japonicus) also are a presence here following fire but, their cover is low and they do not appear to be a serious threat (such as in the Great Basin where they can attain a virtual monoculture status).

\section{Plant Species of Concern}

Three plant species (one a variety) of global significance have been documented from the Upper Tongue River and Hanging Woman drainages of eastern Big Horn and southwestern Rosebud Counties, Montana. They are Barr's milkvetch (Astragalus barrii), Wooly twinpod (Physaria didymocarpa var. lanata), and Nuttall's desert-parsley (Lomatium nuttallii). All are regional endemics, and the latter two ñ wooly twinpod and Nuttall's desert-parsley ñ are restricted in Montana to the upper Tongue River drainage. All are Montana species of concern; Barr's milkvetch and Wooly twinpod are also Wyoming species of concern.

Montana Natural Heritage Program botanists conducted surveys for these plants for the Bureau of Land Management (BLM) during the summers of 2001 and 2002, discovering a total of nine new populations 
(Barton \& Crispin, 2003). While only Wooly twinpod has been documented in the Hanging Woman basin, the habitat for these species is not uncommon in the area, and most likely exists in the basin; thus, there is a good chance that they could occur there.

Table 1 summarizes the status, distribution and habitat characteristics of the globally significant species noted above, as well as five other taxa that have been documented from this general area of Wyoming. Habitat information for the Wyoming taxa is from Dorn (2001). Figure 2 shows their distribution in the region.

Also documented in this general area are a number of plant taxa that are common through a broader range (G5), but rare (S1 or S2) in either Montana and/or Wyoming (Appendix 3).

Table 1. Globally Significant Plant species in the Tongue-Hanging Woman Drainages

\begin{tabular}{|l|l|l|l|}
\hline \multicolumn{1}{|c|}{ Scientific Name } & $\begin{array}{c}\text { Common } \\
\text { Name }\end{array}$ & $\begin{array}{l}\text { Heritage } \\
\text { Ranks }\end{array}$ & \multicolumn{1}{|c|}{ Habitat } \\
\hline Astragalus barrii & $\begin{array}{l}\text { Barr's } \\
\text { milkvetch }\end{array}$ & $\begin{array}{l}\text { G3 } \\
\text { MT: S2S3 } \\
\text { WY: S3 }\end{array}$ & $\begin{array}{l}\text { heavy clay (igumbô̂) knobs, badlands, } \\
\text { buttes and barren hilltops, in sparse } \\
\text { cover of sagebrush and/or pine and } \\
\text { juniper; 3140-4160 ft. }\end{array}$ \\
\hline Lomatium nuttallii & $\begin{array}{l}\text { Nuttall's } \\
\text { desert } \\
\text {-parsley }\end{array}$ & $\begin{array}{l}\text { G3 } \\
\text { MT: S1 } \\
\text { WY: S3 }\end{array}$ & $\begin{array}{l}\text { open, rocky sparsely-vegetated slopes } \\
\text { of sandstone, siltstone or clayey shale, } \\
\text { in open pine woodlands; 2400-7200 ft. }\end{array}$ \\
\hline $\begin{array}{l}\text { Physaria didymocarpa } \text { var. } \\
\text { lanata }\end{array}$ & $\begin{array}{l}\text { Wooly } \\
\text { twinpod }\end{array}$ & $\begin{array}{l}\text { G5T2 } \\
\text { MT: S1 } \\
\text { WY: S2 }\end{array}$ & $\begin{array}{l}\text { slopes on sandstone outcrops, redbed } \\
\text { clay (clinker or scoria)-shale, calcareous } \\
\text { substrates, and road cuts in open } \\
\text { skunkbush sumac \& sagebrush, } \\
\text { occasionally with pine and juniper; } \\
\text { 3300-4100 ft. }\end{array}$ \\
\hline Musineon vaginatum & $\begin{array}{l}\text { Sheathed } \\
\text { musineon }\end{array}$ & G3G4 S2 & rocky hills, woods and slopes \\
\hline Symphyotrichum mollis & Soft aster & G3 S3 & mountain parks and slopes \\
\hline Nothocalais troximoides & $\begin{array}{l}\text { False } \\
\text { agoseris }\end{array}$ & G5 S1 & plains, hills and slopes \\
\hline $\begin{array}{l}\text { Sullivantia hapemanii } \text { var. } \\
\text { hapemanii }\end{array}$ & $\begin{array}{l}\text { Hapeman's } \\
\text { sullivantia }\end{array}$ & G3T3 S3 & wet limestone \\
\hline $\begin{array}{l}\text { Pedicularis contorta } \\
\text { var. ctenophora }\end{array}$ & $\begin{array}{l}\text { Coil-beaked } \\
\text { lousewort }\end{array}$ & G3T3 S2 & Park Reservoir \\
\hline
\end{tabular}




\section{Animals}

\section{Mammals}

The most prominent mammal species of concern present and observed on the Ranch was the Blacktailed Prairie Dog (Cynomys ludovicianus). There are a number of colonies scattered throughout the Hanging Woman Drainage with most of the colonies occupying upslope terraces along the major drainages. The colonies were all fairly small but appeared vigorous with no sign that plague had recently affected the colonies. Control efforts have probably limited these colonies to their current size. The perimeters of a number of these towns were documented by the RMBO (Hanni and Mehlman 2003). Further surveys to document the location, size, and associated species of these Prairie Dog towns should be conducted throughout the region.

Mammal species encountered during a small mammal trapping session on the Forks Ranch included many Deer Mouse (Peromyscus maniculatus), a Northern Grasshopper Mouse (Onychomys leucogaster), and one Merriam's Shrew (Sorex merriami). This effort was confined to sagebrush habitat types and a number other small mammal species of concern such as the Meadow Jumping Mouse (Zapus hudsonius), Preble's Shrew (Sorex preblei), Dwarf Shrew (Sorex nanus) and Hayden's Shrew (Sorex haydeni) may be present in this or other habitat types within the Hanging Woman Basin. The Merriam's Shrew is a Montana species of concern, primarily because so few specimens (9) have been collected in the state (Foresman 2001). This species is one of the most xeric adapted shrews in North America and has been found primarily in sage habitats throughout eastern Montana. The type specimen was collected from near Fort Custer on the Little Bighorn River in Bighorn County in 1884 by C.E.Bendire (Foresman 2001). Additional small mammal surveys in sage habitats in Montana may prove this species to be more common. The Northern Grasshopper Mouse was the first specimen known to be collected from Bighorn County.

Other mammal species of concern that may be present on the ranch include a number of bat species such as the Hoary Bat (Lasiurus cinereus), Pallid Bat (Antrozous pallidus), and Long-eared Myotis (Myotis evotis). One unidentified species of bat was observed foraging in the early evening of August 22,2002 by John Carlson. The composition and distribution of bat fauna in the area is not well known, but species that may be present are noted in Appendix 2.

Additional species of concern that may occur within the basin are the Least Weasel (Mustela nivalis), Swift Fox (Vulpes velox) and Western Spotted Skunk (Spilogale gracilis). Least weasels have been documented in Sheridan Co. Wyoming but not in this area of Montana, although they probably occur here. Swift Fox probably ranged throughout the area in the past, but are now rarely seen here, though populations are thought to be increasing throughout the state.

The distribution of the Spotted Skunks in Montana and Wyoming is poorly known, and there are two species that could occur in the Hanging Woman Basin ñ the Eastern and Western Spotted Skunks. The Western Spotted Skunk has been documented in south central Montana and north central Wyoming in habitats similar to those found on the Forks Unit, and this species may occur in the area. The Eastern Spotted Skunk is not known from Montana but occurs in South Dakota and Wyoming and may also 
occur in this area. Further small mammal and bat surveys would improve our knowledge of the distribution and relative abundance of these species. Mammal occurrences are depicted in Figure 4.

The Hanging Woman Basin and the surround landscape also provide essential winter range for both Antelope or Pronghorn (Antilocapra Americana) and Elk (Cervus elaphus) (Figure 5).

\section{Birds}

Extensive sage habitats in the Hanging Woman Basin potentially provide habitat for a number of sage obligate bird species of concern, Potential Concern, or Under Review in Montana and Wyoming. These include the Greater Sage Grouse (Centrocercus urophasianus), Sage Thrasher (Oreoscoptes montanus), Sage Sparrow (Amphispiza belli), Ferruginous Hawk (Buteo regalis), Brewer's Sparrow (Spizella breweri), Lark Bunting (Calamospiza melanocorys), and Loggerhead Shrike (Lanius ludovicianus). None of these species were observed during our visit, however the timing of our surveys was not optimal for these species. Brewers Sparrows, Lark Buntings and Loggerhead Shrikes were observed by Rocky Mountain Bird Observatory (RMBO) personnel during bird surveys conducted earlier in the summer (Hanni and Mehlman 2003). Sage grouse occur throughout the area, and there are a number of leks noted in the and around the Basin. The status of the sage grouse population in the areas is unknown. Some sage grouse scat was noted during small mammal trapping surveys in August. Although sagebrush habitats are extensive on the Forks Unit and throughout the region, few sage associated species were noted on either the RMBO surveys (Hanni and Mehlman 2003) or during our surveys. This is probably due to the timing of the MTNHP surveys and the number and distribution of the RMBO surveys. Additional surveys throughout sagebrush habitats in the Hanging Woman Basin would better document the occurrence and status of these species.

Species of concern associated with prairie dogs include Burrowing Owls (Athene cunicularia) and Mountain Plovers (Charadrius montanus). Burrowing Owls were noted in a number of prairie dog towns within the drainage by both John Carlson and RMBO personnel. Burrowing Owls are thought to be declining throughout their range in North America and better documentation of their occurrence within the Hanging Woman Basin and throughout Montana is needed. No Mountain Plovers were observed, and there is limited habitat for them in the Basin. Bird occurrences are depicted in Figure 3.

\section{Reptiles}

One Western Rattlesnake (Crotalus viridus) and one Eastern Racer (Coluber constrictor) were observed during small mammal surveys in sagebrush habitats. Other reptiles potentially found in this habitat type on the Forks Ranch include the Gopher or Bull Snake (Pituophis catenifer), Western Hognose Snake (Heterodon nasicus), and the Common Sagebrush Lizard (Sceloporus graciosus). Both the Western Hognose Snake and the Sagebrush Lizard are species of concern in Montana and could potentially exist in a number of habitats on the ranch. The Milk Snake (Lampropeltis triangulum), a species of concern for both Montana and Wyoming, potentially occurs along sandstone outcrops, ridges and escarpments associated with Ponderosa pine communities. These snakes are highly nocturnal and are rarely found even in the appropriate habitat. Surveys for these snakes should be conducted in early June when they are most easily found. Greater Short-horned Lizards (Phrynosoma 
hernandesi), a Montana species of concern, have been found in the basin (Maxell et al. 2003) and probably occur in areas of sparse vegetation throughout.

The Spiny Softshell Turtle (Apalone spiniferus) and the Snapping Turtle are known from the Tongue River. They may occur in Hanging Woman Creek near its mouth and upstream as far as there is yearround water. They probably do not occur as far upstream as the Forks Unit Ranch. Reptile occurrences are depicted in Figure 4.

\section{Amphibians}

No targeted surveys for amphibians were conducted during our brief visit to the area, and no amphibian species of concern were observed. However the Northern Leopard Frog (Rana pipiens), a Montana species of concern, has been observed within the basin (Maxell et al. 2003) and is strongly suspected to occur throughout the basin in appropriate wetland habitat.

The Great Plains Toad (Bufo cognatus) and Plains Spadefoot (Spea bombifrons), both Montana species of concern, have been recorded nearby (Maxell et al. 2003) and probably occur within the Hanging Woman Basin and on the Forks Unit Ranch. Great Plains Toads are found in deserts, grasslands, semidesert shrublands, open floodplains, and agricultural areas, often in stream valleys where soils are softer (Hammerson 1999). When inactive, it is found in burrows, and under rocks or wood. During the active season, it occupies burrows that are quite shallow during the day. This species enters water only to breed, utilizing rain pools, flooded areas, and ponds and reservoirs that fluctuate in size. It appears to prefer stock tanks and roadside ponds rather than floodplains (Baxter and Stone 1985). Eggs and larvae develop in shallow water, usually clear or slightly turbid but not muddy. Plains Spadefoot toads are found in grasslands of plains, hills, floodplains and deserts; sagebrush and semidesert shrublands, usually in areas with friable soils. They burrow underground or occupy rodent burrows when inactive. Eggs and larvae develop in flooded areas and temporary pools formed by heavy rains. Amphibian occurrences are depicted in Figure 4.

\section{Fish}

Although no fish surveys were conducted during our site visit, a number of fish species are known to occur in Hanging Woman Creek (Appendix 1). The only fish species of concern for Montana found in the creek is the Sauger (Stizostedion canadense). This fish probably occurs in the lower reaches of the creek where there is permanent water. The Brassy Minnow (Hybognathus hankinsoni) has also been found in the creek and is a species under review in Montana. Western Silvery Minnow (Hybognathus argyritis), Sturgeon Chub (Hybopsis gelida) and Shovelnose Sturgeon (Scaphirhyncus platorynchus) have been recorded in the Powder River drainage in Wyoming. Fish occurrences are depicted in Figure 3 . 


\section{Discussion AND Conclusions}

\section{Plant Communities}

The topography and landforms on the Forks Ranch appear highly representative of the non-glaciated, sedimentary rock-derived landscape of eastern Montana and Wyoming (known technically as the Powder River Basin / Breaks / Scoria Hills Subsection of the Powder River Basin Section). As would be expected from its relatively low relief and limited geologic variability in the area we surveyed, the plant communities are not highly diverse. We documented only 13 plant associations on the ranch, compared with a the total of approximately 73 community types known to occur in the Powder River Basin Section. Greater community diversity almost certainly does exist on the ranch, particularly in wetland or riparian areas and badlands, which could not be adequately inventoried in this brief assessment. Characterizations of these communities would benefit from more focused assessment in future survey efforts.

\section{Fauna}

Animal surveys were similarly limited by timing and duration, and many species expected in the area were not detected. However, because the Hanging Woman Basin is representative of the surrounding landscape, we were able to develop a list of expected animal species, based on the documented distribution of species in the general area. Additional and more specific surveys conducted on the Forks Ranch would detect many of these species.

The most important animal species present within the Hanging Woman Basin from a conservation perspective are the Black-tailed Prairie Dog and the Greater Sage Grouse. Black-tailed Prairie Dog towns provide habitat not only for the prairie dogs living there but also for a large number of native animal species, including many species of concern (Campbell and Clark 1981, Appendix 2). Similarly, population trends and the distribution of Greater Sage Grouse are assumed be indicative of the health of sagebrush ecosystems throughout Montana and the west (Sage Grouse Working Group 2002). Management of prairie dogs and sage grouse is controversial because of their intimate ties with management of lands for livestock production. Recently published management plans for both species provide further information regarding their management on public and private land in Montana and Wyoming.

\section{Plant Species of Concern}

Though none of the globally significant plant species found in this general landscape were documented on the ranch property surveyed, there is a good likelihood that all occur in the Hanging Woman Basin and may be found with further survey effort. Neither Barr's milkvetch nor Wooly twinpod appear to be negatively impacted by grazing. Both also tend to occupy high knobs and outcrops that are not readily accessible and are poor sites for development. However they may still be vulnerable to secondary impacts that could result from extensive disruption of native vegetation, including the introduction and spread of aggressive invasive weeds that compete with native plant species and reduce habitat quality. Nuttall's desert-parsley grows on mid- to lower-slopes, especially along drainages, and its habitat could be more vulnerable to surface developments. 


\section{Range Quality}

It is difficult to evaluate range condition during severe drought stress and with limited field time.

However, in general, we noted no signs of degraded range such as pedicelling and slopewash erosion. Our short inspection did not reveal any severely overgrazed pastures, though utilization was quite high on a number of areas; this is no doubt a consequence of the ongoing drought and reduced forage yields (assessing stocking rates was beyond the scope of this project). The relative lack of weeds and increaser species also attests to long-term management having been consistent with ecological potential.

\section{Weed Issues}

We noted that hay meadows composed of naturalized pasture grasses have replaced whatever unique communities may have existed in this setting of broad, subirrigated riparian areas (which were noted in passing, not inventoried). These highly manipulated, artificial communities now serve as habitat for an aggressive noxious weed, Euphorbia esula (leafy spurge). Given the mobility of leafy spurge (bird disseminated) it would take very little for it to expand to comparably moist to wet areas, such as native riparian, woody draws and upland swales. We observed Cirsium arvense (Canada thistle) at one riparian location, and a short stretch of the access road to the north had a small population of Hyoscyamus niger (black henbane). We also noted that the herbaceous component of at least one woodland riparian area has been almost completely converted to non-native increasers and the shrub layer compositionally altered as well; it is likely that all such habitat on the ranch where cattle have full access has been degraded to various degrees.

Though not ranked as a noxious weed, Bromus tectorum (cheatgrass) is a pest to livestock operations. It is broadly distributed across the ranch's uplands. Cheatgrass was not noted to be prolific in burned areas or showing potential to become so; this contrasts with B. tectorum's response to burning in Great Basin habitats where it has become a permanent community dominant. With continuing drought this species may gain a competitive advantage over the native grasses, and should be monitored.

While obviously not weed-free, there appears to be remarkably good opportunity to extirpate existing weed populations or, in the case of leafy spurge, simply keep it at low levels in the hay meadows. The ranch has staff permanently dedicated to noxious weed control (spraying in the case of leafy spurge) and though their efforts are dispersed across three units, this should be adequate to control the weeds at current levels. 


\section{Literature Cited}

Barton, D. and S. Crispin. 2003. Globally Significant Plants in Southeastern Big Horn and Southwestern Rosebud Counties, Montana. Montana Natural Heritage Program, Helena. 26 pp. plus appendices.

Baxter, G. T., and M. D. Stone. 1985. Amphibians and reptiles of Wyoming. Second edition. Wyoming Game and Fish Department, Cheyenne, Wyoming. 137 pp.

Campbell, Thomas M. III and Tim W. Clark. 1981. Colony Characteristics and Vertebrate Associates of White-tailed and Black-tailed Prairie Dogs in Wyoming. American Midland Naturalist 105:269-76.

DeVelice, R. L. and P. Lesica. 1993. Plant community classification for vegetation on BLM lands, Pryor Mountains, Carbon County, Montana. Montana Natural Heritage Program, Helena, MT. $78 \mathrm{pp}$.

DeVelice, R. L., S. V. Cooper, J. T. McGarvey, J. Lichthardt, and P. S. Bourgeron. 1995. Plant communities of northeastern Montana: A first approximation. Montana Natural Heritage Program. Helena, MT. 113 pp.

Foresman, K.R. 2001. The Wild Mammals of Montana. Special Publication Number 12, American Society of Mammologists. Lawrence, KS. 278 pp.

Hammerson, G. A. 1999. Amphibians and reptiles in Colorado. Second edition. University Press of Colorado, Niwot, Colorado. 484 pp.

Hanni, D. and D. Mehlman. 2003. 2002 Annual Report: The Affects of Coal-bed Methane Mining on the Breeding Avifauna on Padlock Ranch. Rocky Mountain Bird Observatory, Brighton CO. 15 pp.

Knight, D. H., G. P. Jones, Y. Akashi and R. W. Myers. 1987. Vegetation ecology of the Bighorn Canyon National Recreation Area. Unpublished report submitted to the University of Wyoming-National Park Service Research Center. 114 pp.

Maxell, B. A., J. K. Werner, P. Hendricks, and D. L. Flath. 2003. Herpetology in Montana: a history, status summary, checklists, dichotomous keys, accounts for native, potentially native, and exotic species, and indexed bibliography. Northwest Fauna Number 5. 138 pp.

Montana Bird Distribution. 2003. Montana Bird Distribution Database. http://nhp.nris.state.mt.us/mbd/

Montana Prairie Dog Working Group. 2002. Conservation Plan for Black-tailed and White-tailed Prairie Dogs in Montana. Montana Fish, Wildlife and Parks. Helena MT. 51 pp. 
Montana Sage Grouse Working Group. 2002. Draft Management Plan and Conservation Strategies for Sage Grouse in Montana. Montana Fish, Wildlife and Parks. Helena MT.

NatureServe. 2002. International classification of ecological communities: Terrestrial vegetation.

USDA-NRCS. 1999. Montana Annual Precipitation. National Cartography and Geospatial Center, Fort Worth, TX.

Vanderhorst, J., S. V. Cooper, and B. L. Heidel. 1998. Botanical and vegetation survey of Carter County, Montana. Unpublished report to Bureau of Land Management. Montana Natural Heritage Program. Helena. 116 pp. plus appendices.

Wyoming Natural Diversity Database. 2002. Species of Special Concern. http:// uwadmnweb.uwyo.edu/WYNDD/ 
List of Figures

\section{Figure 1. Sampling locations for plant communities}

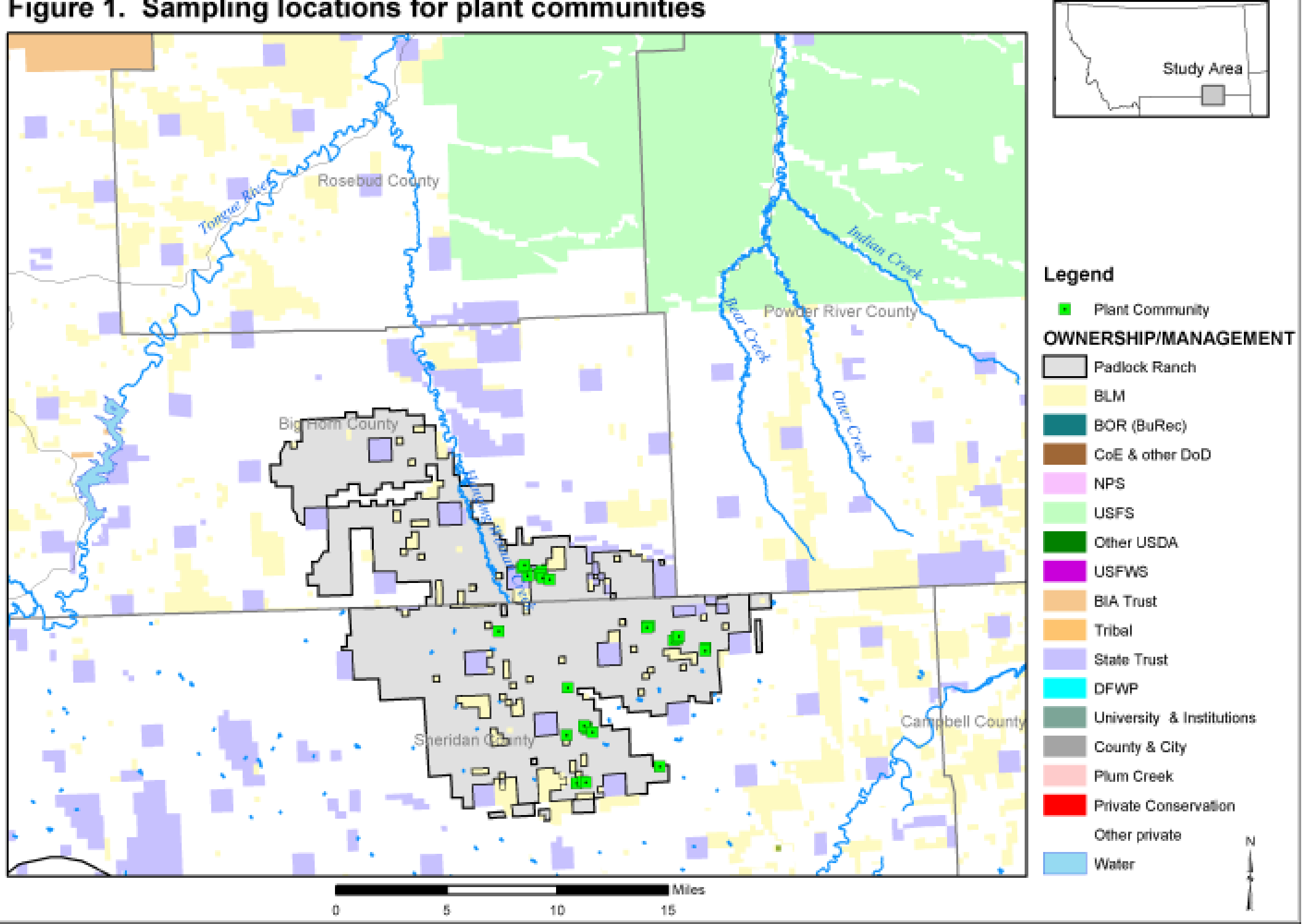




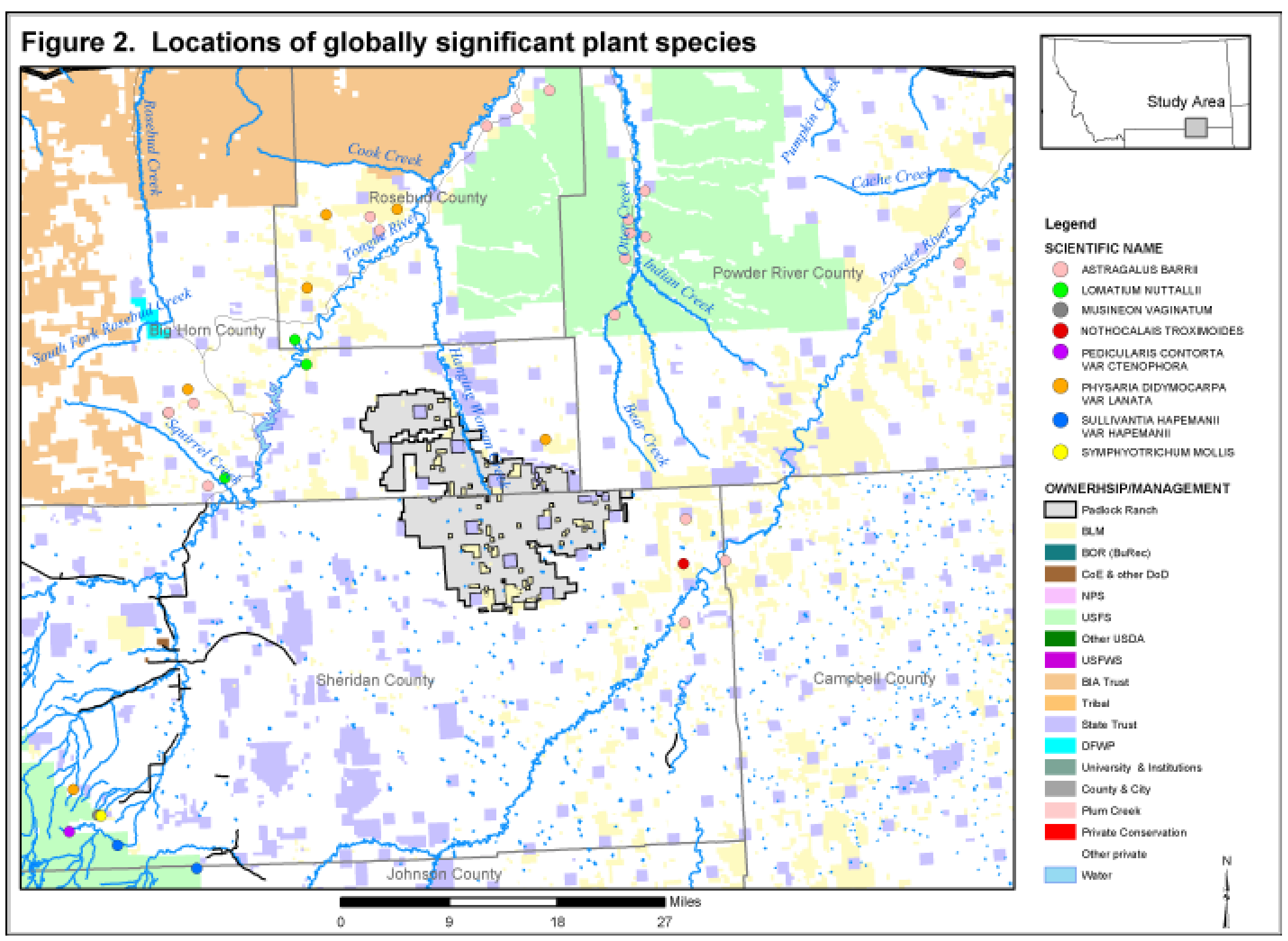




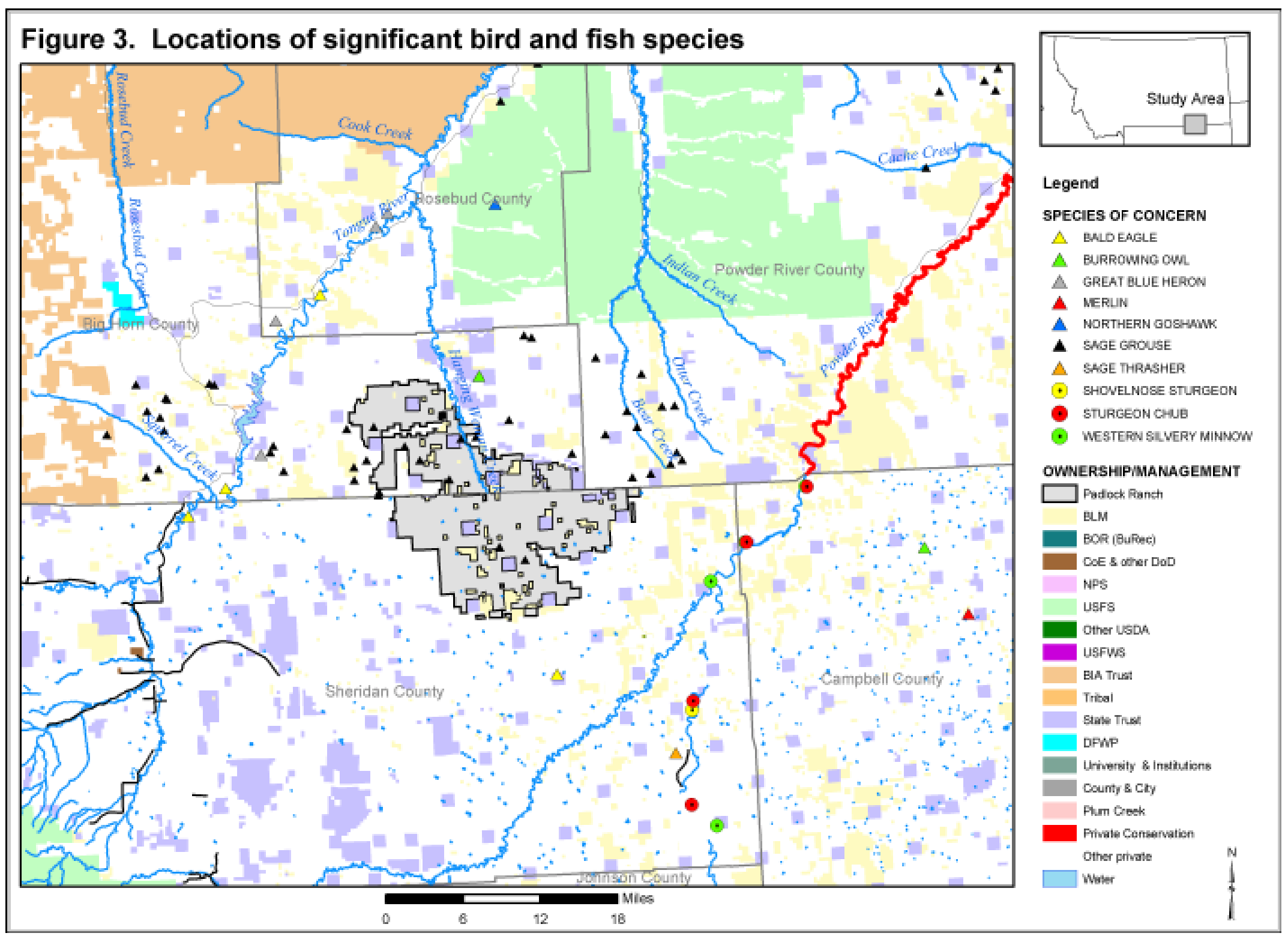




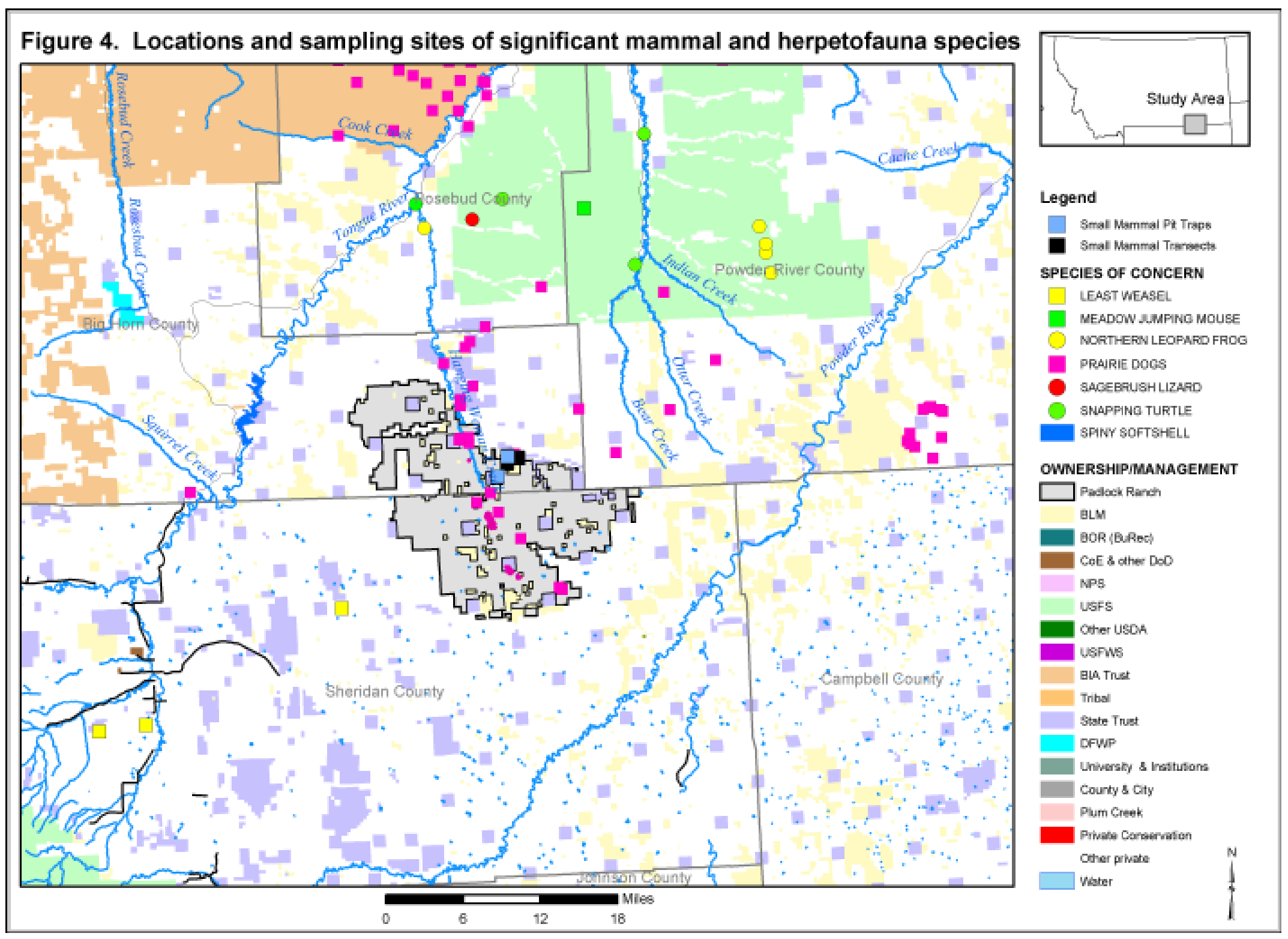




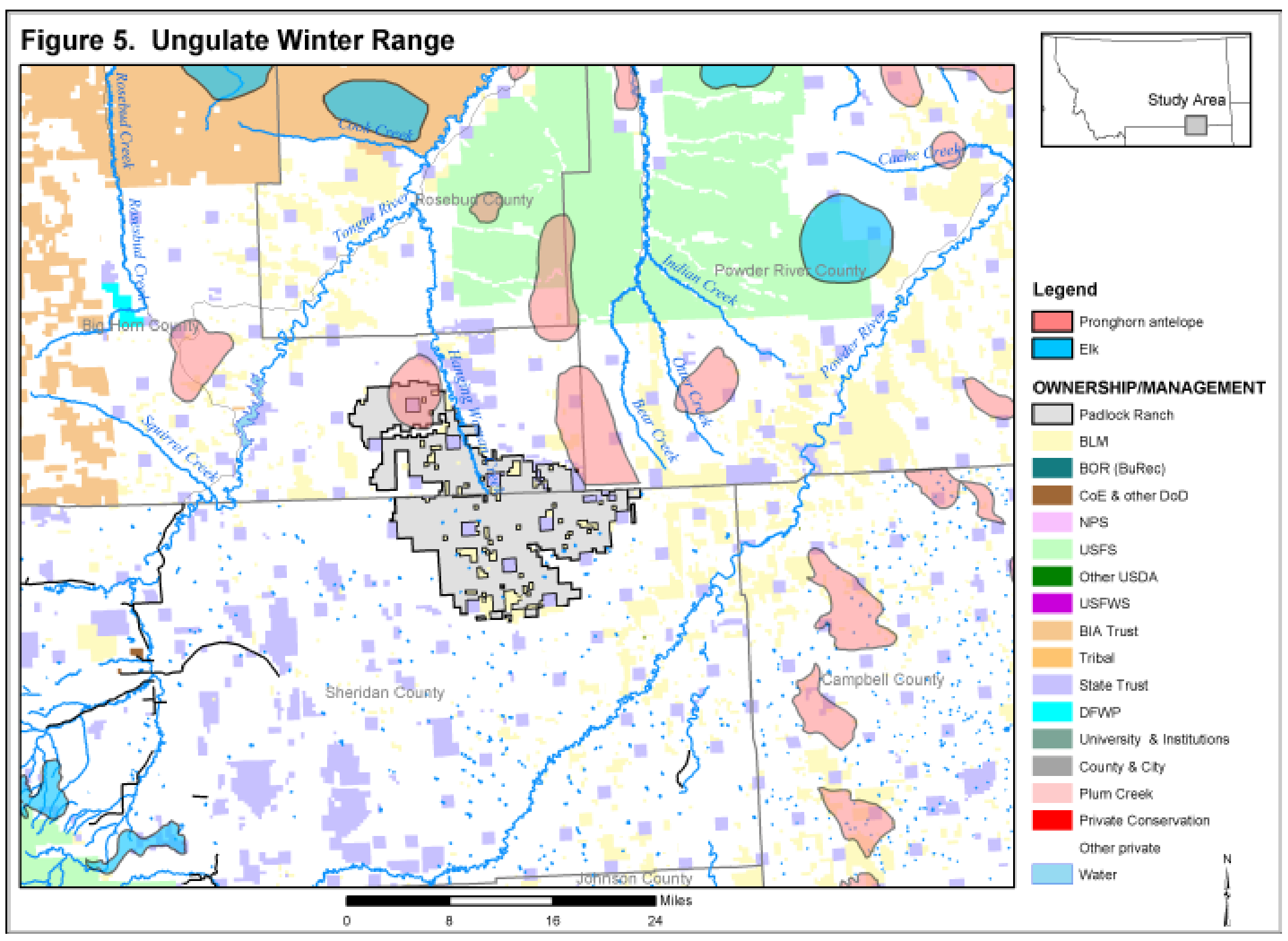




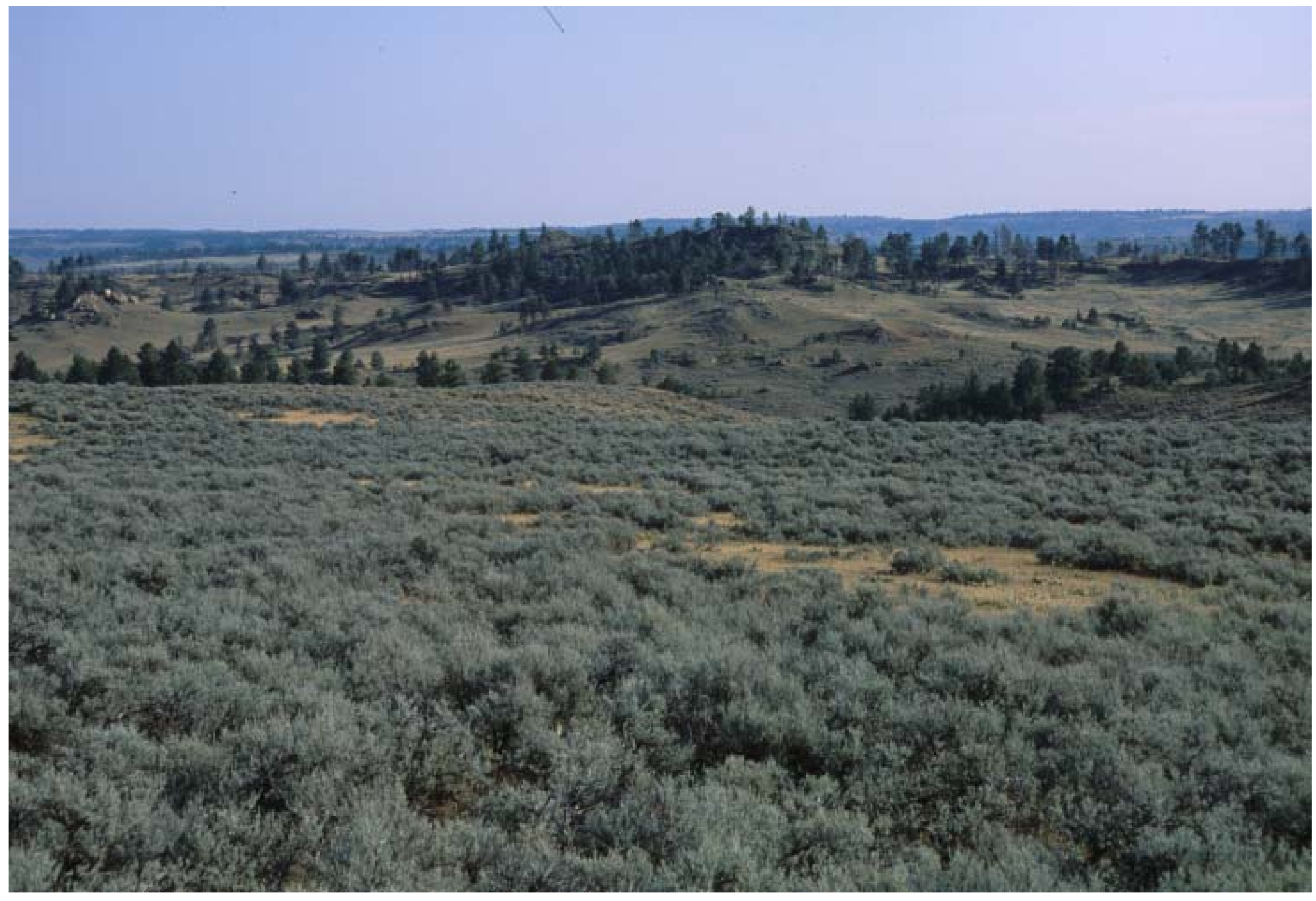

Figure 6: Wyoming big sagebrush (Artemisia tridentata ssp. wyomingensis), occurring on both gently rolling terrain with fine-textured soils and steeper-slope uplands, is by far the most expansive type on the Forks Ranch Unit. 


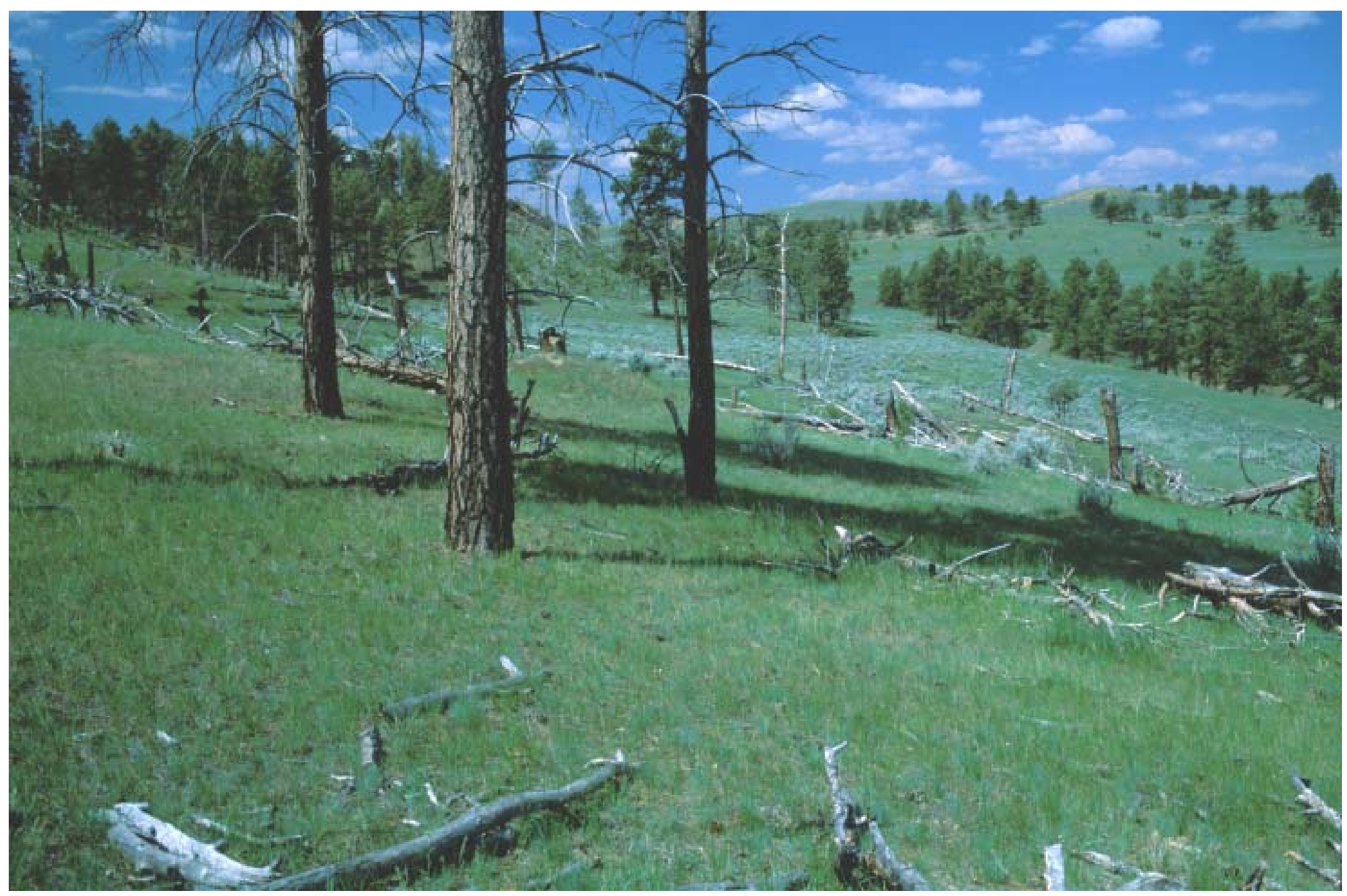

Figure 7: Fire has been an important, mostly natural disturbance across a range of vegetation types on the ranch. Owing to a lack of fuel, fire is generally not stand replacing in woodlands yet recovery to pre-burn structure and composition may take hundreds of years. 


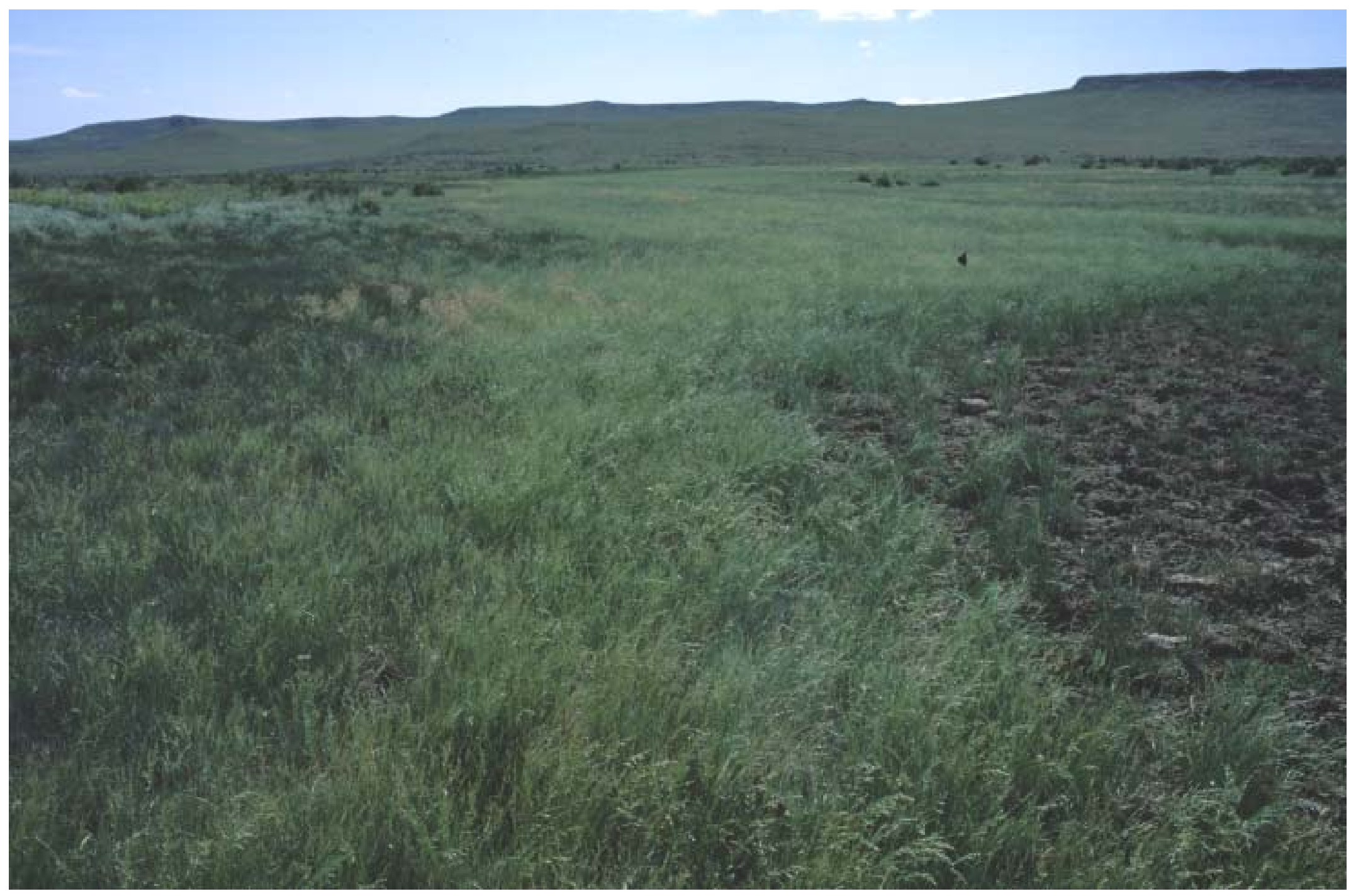

Figure 8: Depending on salt concentration any number of graminoid-dominated communities may develop in bottomlands, such as this sward of Poa juncifolia (big bluegrass, now known as Poa secunda) 


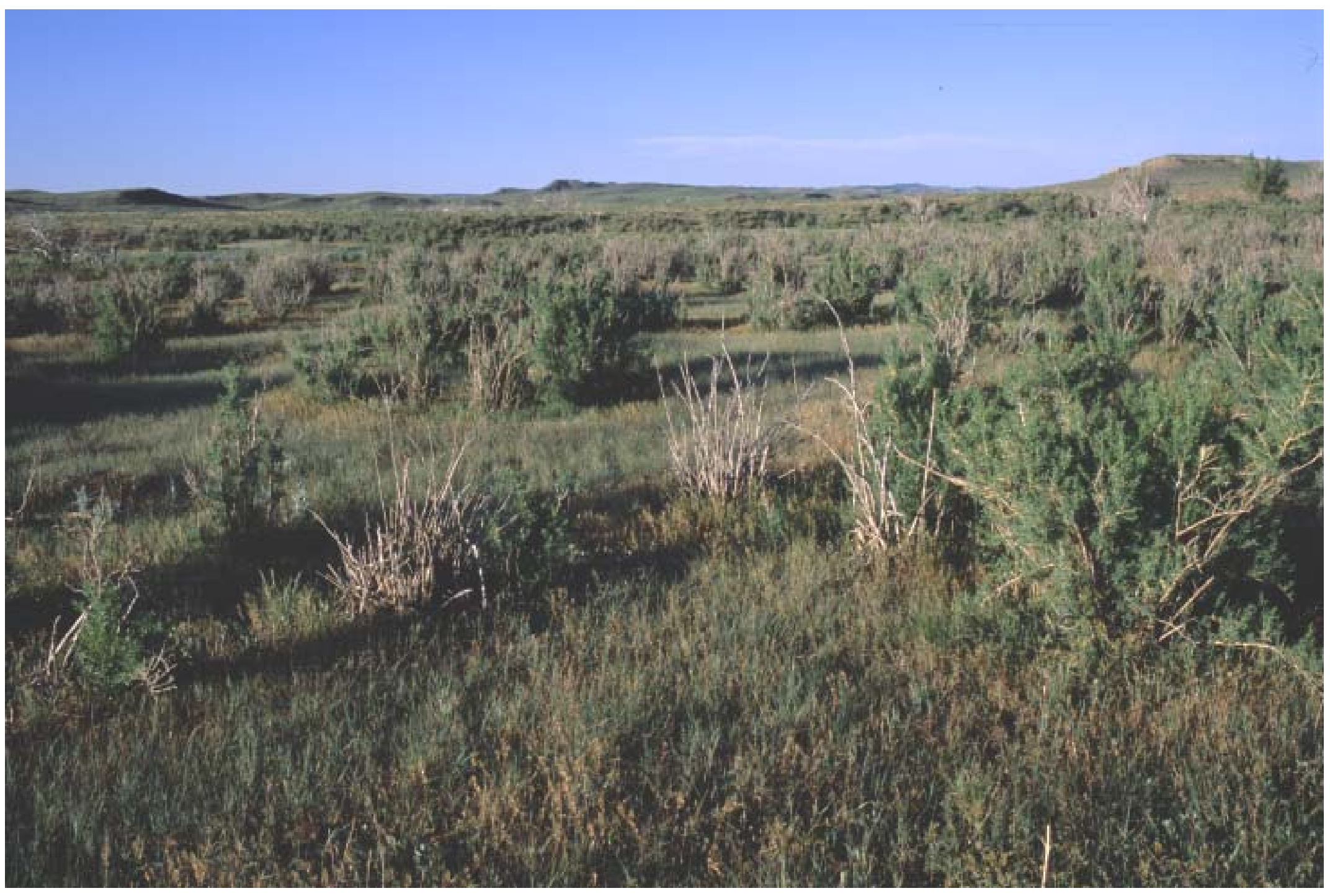

Figure 9: Relatively undisturbed bottomlands are most commonly dominated by black greasewood (Sarcobatus vermiculatus)-dominated communities. 


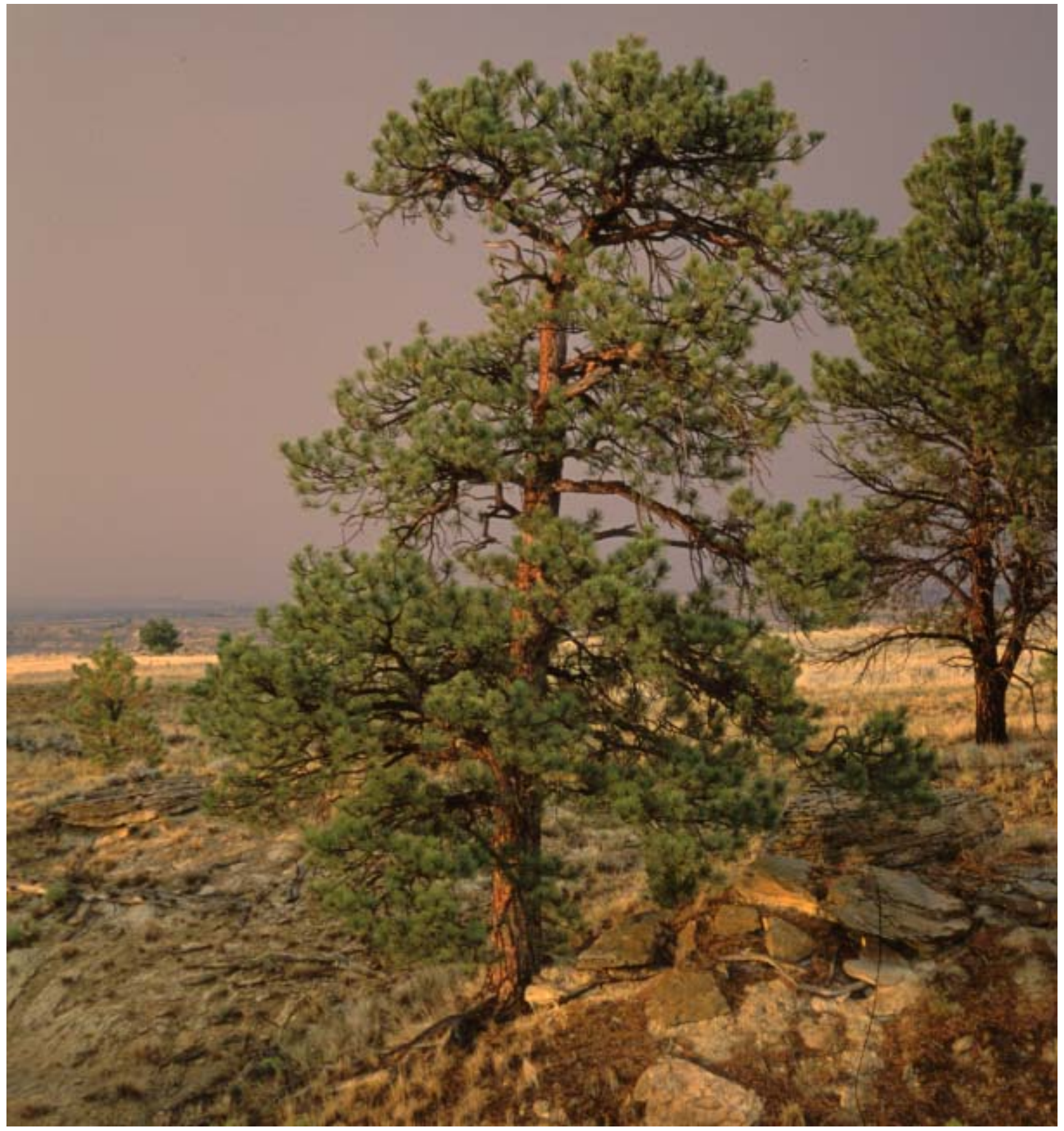

Figure 10: Pinus ponderosa, both woodlands and scattered individuals, populate the sandstone caprock formations. 
Appendix 1. Global/State Rank Definitions 


\section{HERITAGE PROGRAM RANKS}

The international network of Natural Heritage Programs employs a standardized ranking system to denote global (range-wide) and state status (NatureServe 2002). Species are assigned numeric ranks ranging from 1 (critically imperiled) to 5 (demonstrably secure), reflecting the relative degree to which they are ìat-riskî. Rank definitions are given below. A number of factors are considered in assigning ranks ó the number, size and distribution of known ìoccurrencesî or populations, population trends (if known), habitat sensitivity, and threat. Factors in a species'life history that make it especially vulnerable are also considered (e.g., dependence on a specific pollinator).

\section{RANK DEFINITIONS}

G1 S1 Critically imperiled because of extreme rarity and/or other factors making it highly vulnerable to extinction.

G2 S2 Imperiled because of rarity and/or other factors making it vulnerable to extinction.

G3 S3 Vulnerable because of rarity or restricted range and/or other factors, even though it may be abundant at some of its locations.

G4 S4 Apparently secure, though it may be quite rare in parts of its range, especially at the periphery.

G5 S5 Demonstrably secure, though it may be quite rare in parts of its range, especially at the periphery.

GU SU Possibly imperiled, but status uncertain; more information needed.

GA SA Native in nearby states, but in Montana believed to be accidentally introduced, deliberately planted, or escaped from plantings.

GH SH Historical, known only from records over 50 year ago; may be rediscovered.

GX SX Believed to be extinct; historical records only.

\section{COMBINATION RANKS}

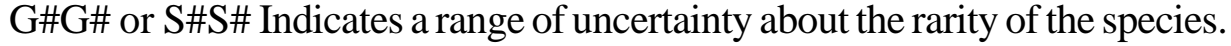

\section{SUBRANKS}

T\# Rank of a subspecies or variety; appended to the species' global rank of the full species, e.g. G4T3.

\section{QUALIFIERS}

Taxonomic questions or problems exist, more information needed; appended to the global rank, e.g. G3Q. 
Appendix 2. Animal Species in the Hanging Woman Basin. 
Appendix 2. List of animal species for the Hanging Woman Basin. These species have been documented for the area or are suspected of occurring in the area. The list was generated from a variety of sources including: Montana Bird Distribution Website [http://nhp.nris.state.mt.us/mbd/], Foresman (2001), Hanni and Mehlman (2003), Maxell (2003) and Wyoming Natural Diversity Database (2002).

\begin{tabular}{|c|c|c|c|}
\hline Common Name & Scientific Name & MT Status & WY status \\
\hline \multicolumn{4}{|l|}{ AMPHIBIANS } \\
\hline Great Plains Toad & Bufo cognatus & Species of Concern & \\
\hline Woodhouse's Toad & Bufo woodhousii & & \\
\hline Plains Spadefoot & Spea bombifrons & Species of Concern & \\
\hline Northern Leopard Frog & Rana pipiens & Species of Concern & Species of Special Concern \\
\hline \multirow{2}{*}{\multicolumn{4}{|c|}{ BIRDS }} \\
\hline Double-crested Cormorant & Phalacrocorax auritus & & \\
\hline Great Blue Heron & Ardea herodias & & \\
\hline Canada Goose & Branta canadensis & & \\
\hline Wood Duck & Aix sponsa & & \\
\hline Green-winged Teal & Anas crecca & & \\
\hline Mallard & Anas platyrhynchos & & \\
\hline \begin{tabular}{|l|} 
Northern Pintail \\
\end{tabular} & Anas acuta & & \\
\hline Blue-winged Teal & Anas discors & & \\
\hline \begin{tabular}{|l} 
Northern Shoveler \\
\end{tabular} & Anas clypeata & & \\
\hline Gadwall & Anas strepera & & \\
\hline American Wigeon & Anas americana & & \\
\hline Turkey Vulture & Cathartes aura & & \\
\hline Osprey & Pandion haliaetus & & \\
\hline Bald Eagle & Hallaeetus leucocephalus & Species of Concern & Species of Special Concern \\
\hline \begin{tabular}{|l} 
Northern Harrier \\
\end{tabular} & Circus cyaneus & & \\
\hline Sharp-shinned Hawk & Accipiter striatus & & \\
\hline Cooper's Hawk & Accipiter coopenii & & \\
\hline Northern Goshawk & Acciplter gentilis & Species of Concern & Species of Special Concern \\
\hline Swainson's Hawk & Buteo swainsoni & Potential Concern & \\
\hline Red-tailed Hawk & Buteo jamaicensis & & \\
\hline Ferruginous Hawk & Buteo regalls & Species of Concern & \\
\hline Rough-legged Hawk & Buteo lagopus & & \\
\hline Golden Eagle & Aquila chrysaetos & & \\
\hline American Kestrel & Falco sparverius & & \\
\hline Merlin & Falco columbarius & & Species of Special Concern \\
\hline Prairie Falcon & Falco mexicanus & & \\
\hline Gray Partridge & Perdix perdix & & \\
\hline Ring-necked Pheasant & Phasianus colchicus & & \\
\hline Greater Sage Grouse & Centrocercus urophasianus & Potential Concern & \\
\hline Sharp-tailed Grouse & Tympanuchus phasianellus & & \\
\hline Wild Turkey & Meleagris gallopavo & & \\
\hline American Coot & Fulica americana & & \\
\hline Killdeer & Charadrius vociferus & & \\
\hline Mountain Plover & Charadrius montanus & Species of Concern & Species of Special Concern \\
\hline Greater Yellowlegs & \begin{tabular}{|l|} 
Tringa melanoleuca \\
\end{tabular} & & \\
\hline Lesser Yellowlegs & Tringa flavipes & & \\
\hline Solitary Sandpiper & Tringa solitaria & & \\
\hline Willet & Catoptrophorus semipalmatus & & \\
\hline Spotted Sandpiper & Actitis macularia & & \\
\hline Upland Sandpiper & Bartramia longicauda & & \\
\hline Long-billed Curlew & Numenius americanus & Potential Concern & \\
\hline Wilson's Phalarope & Phalaropus tricolor & & \\
\hline Ring-billed Gull & Larus delawarensis & & \\
\hline California Gull & Larus californicus & & \\
\hline Rock Dove & Columba livia & & \\
\hline Mourning Dove & Zenaida macroura & & \\
\hline Barn Owl & Tyto alba & Species of Concern & Species of Special Concern \\
\hline Eastern Screech-owl & Otus asio & On Review & \\
\hline Burrowing Owl & Athene cunicularia & Species of Concern & Species of Special Concern \\
\hline Long-eared Owl & Asio otus & & \\
\hline
\end{tabular}
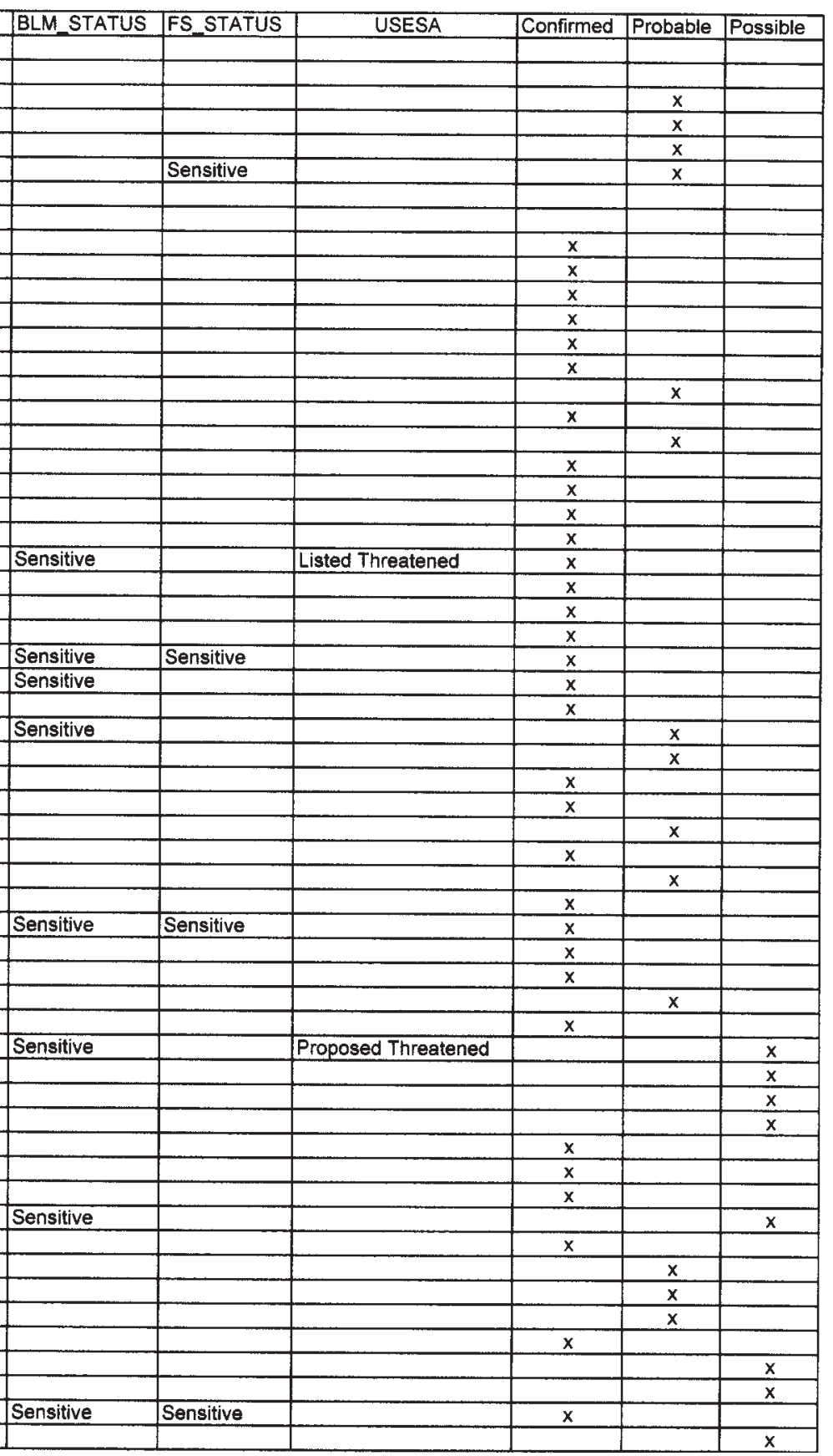


\begin{tabular}{|c|c|c|c|c|c|c|c|c|c|}
\hline Common Name & Scientific Name & MT Status & WY status & BLM_STATUS & FS STATUS & USESA & Confirmed & Probable & Possible \\
\hline Shot-ered Oul & Aclo flamma & & & & & & & & \\
\hline Common Nighthawk & Chordeiles minor & & & & & & $x$ & & $x$ \\
\hline Common Poorwill & Phalaenoptilus nuttallii & On Review & & & & & $x$ & & \\
\hline While-throated Swift & Aeronautes saxatalis & & & & & & $\frac{\hat{x}}{x}$ & & \\
\hline Ruby-throated Hummingbird & Archilochus colubris & & & & & & & & $\bar{x}$ \\
\hline Belted Kingrisher & Ceryle alcyon & & & & & & & $x$ & \\
\hline Lewis' Woodpecker & Melanerpes low/s & Species of Concerm & Species of Special Concern & & & & & & $\bar{x}$ \\
\hline Red-headed Woodpecker & Melanerpes erythrocephalus & Species of Concern & & & & & $\bar{x}$ & & \\
\hline Downy Woodpecker & Picoides pubescens & & & & & & & $\bar{x}$ & \\
\hline Hairy Woodpecker & Picoides villosus & & & Sensitive & & & $\bar{x}$ & & \\
\hline Three-toed Woodpecker & Picoldes tridactylus & On Review & & Sensitive & & & & $x$ & \\
\hline Black-backed Woodpecker & Picoides arcticus & Species of Concern & Species of Special Concern & Sensitive & Sensitive & & $\bar{x}$ & & \\
\hline Northern Flicker & Colaptes auratus & & & & & & $x$ & & \\
\hline Western Wood-pewee & Contopus sordidulus & & & & & & $\frac{\hat{x}}{x}$ & & \\
\hline Least Flycatcher & Empidonax minimus & & & & & & $\bar{x}$ & & \\
\hline Dusky Flycatcher & Empidonax oberholseri & & & & & & $\frac{x}{x}$ & & \\
\hline Say's Phoebe & Sayornis saya & & & & & & $x$ & & \\
\hline Cassin's KIngbird & Tyrannus voctferans & Species of Concern & Species of Special Concern & & & & $\bar{x}$ & & \\
\hline Western Kingbird & Tyrannus verticalis & & & & & & $\frac{n}{x}$ & & \\
\hline Eastern Kingbird & Tyrannus tyrannus & & & & & & $\bar{x}$ & & \\
\hline Horned Lark & Eremophila alpestris & & & & & & $\frac{x}{x}$ & & \\
\hline Tree Swallow & Tachycineta bicolor & & & & & & & $\bar{x}$ & \\
\hline Violet-green Swallow & Tachycineta thalassina & & & & & & $\mathrm{x}$ & & \\
\hline Northern Rough-winged Swallow & Stelgidopteryx serripennis & & & & & & & $x$ & \\
\hline Bank Swallow & Riparia riparia & & & & & & $\bar{x}$ & & \\
\hline Cliff Swallow & Petrochelidon pyrrhonota & & & & & & $x$ & & \\
\hline Barn Swallow & Hirundo rustica & & & & & & $\frac{x}{x}$ & & \\
\hline Pinyon Jay & Gymnorhinus cyanocephalus & & & & & & $\bar{x}$ & & \\
\hline Clark's Nutcracker & Nucifraga columbiana & & & & & & & & $\bar{x}$ \\
\hline Black-billed Magpie & Pica pica & & & & & & $\bar{x}$ & & \\
\hline American Crow & Corvus brachyrhynchos & & & & & & $x$ & & \\
\hline Common Raven & Corvus corax & & & & & & & & $\bar{x}$ \\
\hline Black-capped Chickadee & Poecile atricapillus & & & & & & $\bar{x}$ & & \\
\hline Mountain Chickadee & Poecile gambeli & & & & & & & & $\bar{x}$ \\
\hline Red-breasted Nuthatch & Sitta canadensis & & & & & & $x$ & & \\
\hline White-breasted Nuthatch & \begin{tabular}{|l} 
Sitta carolinensis \\
\end{tabular} & & & & & & $x$ & & \\
\hline Pygmy Nuthatch & Sitta pygmaed & & Species of Special Concern & & & & & & $x$ \\
\hline Brown Creeper & Certhia americana & & & & & & & & $x$ \\
\hline Rock Wren & Salpinctes obsoletus & & & & & & $\bar{x}$ & & \\
\hline Canyon Wren & \begin{tabular}{|l|} 
Catherpes mexicanus \\
\end{tabular} & & & & & & $x$ & & \\
\hline House Wren & Troglodytes aedon & & & & & & $x$ & & \\
\hline Eastern Bluebird & $\begin{array}{l}\text { Sialla sialis } \\
\end{array}$ & Species of Concern & Species of Special Concern & & & & & & $x$ \\
\hline Mountain Bluebird & Sialia currucoides & & & & & & $\bar{x}$ & & \\
\hline Townsend's Solitaire & Myadestes townsendi & & & & & & & & $\bar{x}$ \\
\hline Veery & Catharus fuscescens & & & & & & $\mathrm{x}$ & & \\
\hline American Robin & Tundus migratorius & & & & & & $x$ & & \\
\hline Gray Catbird & Dumetella carolinensis & & & & & & $x$ & & \\
\hline Northern Mockingbird & Mimus polyglottos & & & & & & $x$ & & \\
\hline Sage Thrasher & Oreoscoptes montanus & On Review & & & & & $x$ & & \\
\hline Brown Thrasher & Toxostome rufum & & & & & & $x$ & & \\
\hline Cedar Waxwing & Bombycilla cedrorum & & & & & & $x$ & & \\
\hline Northern Shrike & Lanius excubitor & & & & & & & & $\bar{x}$ \\
\hline Loggerhead Shrike & Lanius /udovicianus & & & Sensitive & Sensitive & & $\bar{x}$ & & \\
\hline European Starling & $\begin{array}{l}\text { Stumus vulgaris } \\
\end{array}$ & & & & & & $\bar{x}$ & & \\
\hline Warbling Vireo & Vireo gilvus & & & & & & & $\mathrm{x}$ & \\
\hline Plumbeous Vireo & Vireo plumbeus & On Review & & & & & $\bar{x}$ & & \\
\hline Yellow Warbler & Dendroica petechía & & & & & & $x$ & & \\
\hline Yellow-rumped Warbler & Dendroica coronata & & & & & & $\frac{\hat{x}}{x}$ & & \\
\hline American Redstart & Setophaga ruticilla & & & & & & $x$ & & \\
\hline Ovenbird & Seiurus aurocapillus & & & & & & $\frac{\pi}{x}$ & & \\
\hline Common Yellowthroat & Geothlypis trichas & & & & & & $x$ & & \\
\hline Yellow-breasted Chat & \begin{tabular}{|l} 
Icteria virens \\
\end{tabular} & & & & & & $\frac{1}{x}$ & & \\
\hline
\end{tabular}




\begin{tabular}{|c|c|c|c|c|c|c|c|c|c|}
\hline Common Name & Scientific Name & MT Status & WY status & BLM_STATUS & FS_STATUS & USESA & Confirmed & Probable & Possible \\
\hline Western Tanager & Piranga ludoviciana & & & & & & & & \\
\hline Black-headed Grosbeak & Pheucticus melanocephalus & & & & & & $x$ & & \\
\hline Lazuli Bunting & Passerina amoena & & & & & & $x$ & & \\
\hline Green-tailed Towhee & Pipilo chlorurus & & & & & & $\underline{x}$ & & \\
\hline Spolted Towhee & Pipilo maculatus & & & & & & $\underline{x}$ & & \\
\hline American Tree Sparrow & Spizella arborea & & & & & & $x$ & & \\
\hline Chipping Sparrow & Spizella passerina & & & & & & & & $\mathbf{x}$ \\
\hline Clay-colored Sparrow & Spizella pallida & & & & & & $x$ & & \\
\hline Brewer's Sparrow & Spizel/a breweri & Potential Concern & Species of Special Concern & & & & & $x$ & \\
\hline Field Sparrow & Spizella pusilla & & & & & & $\frac{x}{x}$ & & \\
\hline Vesper Sparrow & Pooecetes gramineus & & & & & & $\frac{n}{x}$ & & \\
\hline Lark Sparrow & Chondestes grammacus & & & & & & $\bar{x}$ & & \\
\hline Sage Sparrow & Amphispiza belli & On Review & Species of Special Concern & Sensitive & & & & & $x$ \\
\hline Lark Bunting & Calamospiza melanocorys & & & & & & $\bar{x}$ & & \\
\hline Savannah Sparrow & Passerculus sandwichensis & & & & & & & $\mathrm{x}$ & \\
\hline Grasshopper Sparrow & Ammodramus savannarum & Potential Concern & Species of Special Concern & & & & $\bar{x}$ & & \\
\hline Song Sparrow & Melospiza melodia & & & & & & $x$ & & \\
\hline Dark-eyed Junco & Junco hyemalis & & & & & & $x$ & & \\
\hline Bobolink & Dolichonyx oryzivorus & & & & & & & & $\bar{x}$ \\
\hline Red-winged Blackbird & Agelaius phoeniceus & & & & & & $x$ & & \\
\hline Western Meadowlark & Sturnella neglecta & & & & & & $x$ & & \\
\hline Yellow-headed Blackbird & Xanthocephalus xanthocephalus & & & & & & $\bar{x}$ & & \\
\hline Brewer's Blackbird & Euphagus cyanocephalus & & & & & & $\bar{x}$ & & \\
\hline Common Grackle & Quiscalus quiscula & & & & & & $\bar{x}$ & & \\
\hline Brown-headed Cowbird & Molothrus ater & & & & & & $x$ & & \\
\hline Bullock's Oriole & Icterus bullockii & & & & & & $\bar{x}$ & & \\
\hline Cassin's Finch & Carpodacus cassinii & & & & & & $x$ & & \\
\hline House Finch & Carpodacus mexicanus & & & & & & & $x$ & \\
\hline Red Crossbill & Loxia curvirostra & & & & & & $x$ & & \\
\hline Pine Siskin & Carduelis pinus & & & & & & $x$ & & \\
\hline American Goldfinch & Carduelis tristis & & & & & & $x$ & & \\
\hline Evening Grosbeak & Coccothraustes vespertinus & & & & & & $x$ & & \\
\hline House Sparrow & Passer domesticus & & & & & & $x$ & & \\
\hline \multirow{2}{*}{\multicolumn{10}{|c|}{ FISH }} \\
\hline Northern Pike & Esoxlucius & & & & & & & & \\
\hline Lake Chub & Couesius plumbeus & & & & & & $x$ & & \\
\hline Common Carp & Cyprinus carpio & & & & & & $x$ & & \\
\hline Brassy Minnow & Hybognathus hankinsoni & On Review & & & & & $\frac{x}{x}$ & & \\
\hline Golden Shiner & Notemigonus crysoleucas & & & & & & $\frac{\hat{x}}{x}$ & & \\
\hline Sand Shiner & Notropis stramineus & & & & & & $\frac{x}{x}$ & & \\
\hline Fathead Minnow & Pimephales promelas & & & & & & $\bar{x}$ & & \\
\hline Longnose Dace & Rhinichthys cataractae & & & & & & $x$ & & \\
\hline River Carpsucker & Carpiodes carpio & & & & & & $x$ & & \\
\hline Longnose Sucker & Catostomus catostomus & & & & & & $x$ & & \\
\hline White Sucker & Catostomus commersoni & & & & & & $x$ & & \\
\hline Shorthead Redhorse & Moxostoma macrolepidotum & & & & & & $\bar{x}$ & & \\
\hline Stonecat & Noturus flavus & & & & & & $x$ & & \\
\hline Black Bullhead & Ictalurus melas & & & & & & $x$ & & \\
\hline Rock Bass & Ambloplites rupestris & & & & & & $x$ & & \\
\hline Green Sunfish & Lepomis cyanellus & & & & & & $x$ & & \\
\hline Pumpkinseed & Lepomis gibbosus & & & & & & $\mathbf{x}$ & & \\
\hline Smallmouth Bass & Micropterus dolomieu & & & & & & $x$ & & \\
\hline White Crappie & Pomoxis annularis & & & & & & $x$ & & \\
\hline Yellow Perch & Perca flavescens & & & & & & $x$ & & \\
\hline Sauger & Stizostedion canadense & Species of Concern & & & & & $x$ & & \\
\hline Walleye & Stizostedion vitreum & & & & & & $x$ & & \\
\hline \multicolumn{10}{|l|}{ MAMMALS } \\
\hline Masked Shrew & Sorex cinereus & & & & & & & $x$ & \\
\hline Preble's Shrew & Sorex preb/el & Species of Concern & & Sensitive & & & & $x$ & \\
\hline Dwarf Shrew & Sorex nanus & Species of Concern & Species of Special Concern & & & & & & $\bar{x}$ \\
\hline
\end{tabular}




\begin{tabular}{|c|c|c|c|c|c|c|c|c|c|}
\hline Common Name & Scientific Name & MT Status & Wr status & BLM_STATUS & FS_STATUS & USESA & Confirmed & Probable & Possible \\
\hline & & & & & & & & & \\
\hline Water Shrew & Sorex palustris & & & & & & & $x$ & \\
\hline Merriam's Shrew & Sorex merriaml & Species of Concern & & Sensitive & & & & $\frac{n}{x}$ & \\
\hline Hayden's Shrew & Sorex haydenl & Species of Concern & Species of Special Concern & & & & & & $\bar{x}$ \\
\hline Little Brown Myotis & Myotis lucifugus & & & & & & & $x$ & \\
\hline Yuma Myotis & Myotis yumanensis & Species of Concern & Species of Special Concern & & & & & & $\bar{x}$ \\
\hline Long-eared Myotis & Myotis avotis & Species of Concern & Species of Special Concern & & & & & $x$ & \\
\hline Long-legged Myotis & Myotis volans & & & & & & & $x$ & \\
\hline Western Small-footed Myotis & Myotis ciliolabrum & & & & & & & $\frac{x}{x}$ & \\
\hline Silver-haired Bat & Lasionycteris noctivagans & & & & & & & $\frac{n}{x}$ & \\
\hline Big Brown Bat & Eptesicus fuscus & & & & & & & $\bar{x}$ & \\
\hline Hoary Bat & Lasiurus cinerous & & Species of Special Concern & & & & & $x$ & \\
\hline Townsend's Big-eared Bat & Corynorhinus townsendii & Species of Concern & Species of Special Concern & Sensitive & Sensitive & & & $x$ & \\
\hline Pallid Bat & \begin{tabular}{|l} 
Antrozous pallidus \\
\end{tabular} & Species of Concern & Species of Special Concern & & Sensitive & & & & $x$ \\
\hline Mountain Cottontail & Sylvilagus nuttallii & & & & & & & $x$ & \\
\hline Desert Cottontail & Sylvilagus audubonii & & & & & & & $x$ & \\
\hline White-tailed Jack Rabbit & Lepus townsendii & & & & & & & $\frac{\hat{x}}{x}$ & \\
\hline Least Chipmunk & Tamias minimus & & & & & & $x$ & & \\
\hline Thirteen-lined Ground Squirrel & Spermophilus tridecemlineatus & & & & & & & & $\bar{x}$ \\
\hline Black-tailed Prairie Dog & Cynomys ludovicianus & Species of Concern & Species of Special Concern & Sensitive & Sensitive & Candidate & $\bar{x}$ & & \\
\hline Northern Pocket Gopher & Thomomys talpoides & & & & & & & $\bar{x}$ & \\
\hline Olive-backed Pocket Mouse & Perognathus fasciatus & & & & & & & $x$ & \\
\hline Ord's Kangaroo Rat & Dipodomys ordii & & & & & & & $\hat{x}$ & \\
\hline Western Harvest Mouse & Reithrodontomys megalotis & & & & & & & $x$ & \\
\hline Deer Mouse & Peromyscus maniculatus & & & & & & $x$ & & \\
\hline White-footed Mouse & Peromyscus leucapus & & & $\$ 4$ & & & & & $x$ \\
\hline Northern Grasshopper Mouse & Onychomys leucogaster & & & & & & $\bar{x}$ & & \\
\hline Bushy-tailed Woodrat & Neotoma cinerea & & & & & & & $\bar{x}$ & \\
\hline Meadow Vole & Microtus pennsy/vanicus & & & & & & & $x$ & \\
\hline Long-tailed Vole & Microtus longicaudus & & & & & & & $x$ & \\
\hline Prairie Vole & Microtus ochrogaster & & & & & & & $x$ & \\
\hline Sagebrush Vole & \begin{tabular}{|l|} 
Lagurus curtatus \\
\end{tabular} & & & & & & & & $x$ \\
\hline Muskrat & Ondatra zibethicus & & & & & & & $\bar{x}$ & \\
\hline Meadow Jumping Mouse & Zapus hudsonius & Species of Concern & & Sensitive & & & & $x$ & \\
\hline Western Jumping Mouse & Zapus princeps & & & & & & & $x$ & \\
\hline Common Porcupine & Erethizon dorsatum & & & & & & & $x$ & \\
\hline Coyote & Canis latrans & & & & & & $\bar{x}$ & & \\
\hline Red Fox & Vulpes vulpes & & & & & & & & $x$ \\
\hline Swift Fox & Vulpes velox & Species of Concern & Species of Special Concern & Sensitive & Sensitive & & & & $x$ \\
\hline Black Bear & Ursus americanus & & & & & & & & $x$ \\
\hline Common Raccoon & Procyon lotor & & & & & & & $\bar{x}$ & \\
\hline Least Weasel & Mustela nivalis & Species of Concern & Species of Special Concern & & & & & $\frac{\hat{x}}{x}$ & \\
\hline Long-tailed Weasel & Mustela frenata & & & & & & & $\bar{x}$ & \\
\hline Mink & Mustela vison & & & & & & & $x$ & \\
\hline American Badger & Taxidea taxus & & & & & & & $x$ & \\
\hline Eastern Spotted Skunk & Spilogale putorius & & & Sensitive & & & & & $x$ \\
\hline Western Spotted Skunk & Spilogale gracills & Species of Concern & & & & & & & $x$ \\
\hline Striped Skunk & Mephitis mephitis & & & & & & & $x$ & \\
\hline Bobcat & Felis rufus & & & & & & & $x$ & \\
\hline Mountain Lion & Felis concolor & & & & & & & $x$ & \\
\hline Wapiti Or Elk & Cervus elaphus & & & & & & $x$ & & \\
\hline Mule Deer & Odocoileus hemionus & & & & & & $x$ & & \\
\hline White-tailed Deer & Odocoileus virginianus & & & & & & & $\bar{x}$ & \\
\hline Pronghorn & Antilocapra americana & & & & & & $x$ & & \\
\hline \multirow{2}{*}{\multicolumn{10}{|c|}{ REPTILES }} \\
\hline & & & & Sensitive & & & & & $\sqrt{x}$ \\
\hline Painted Turtle & Chrysemys picta & & & & & & $\bar{x}$ & & \\
\hline Sagebrush Lizard & Sceloporus graciosus & Species of Concern & & & & & $x$ & & \\
\hline Racer & Coluber constrictor & & & & & & $x$ & & \\
\hline Western Hognose Snake & Heterodon nasicus & & & & & & & & $x$ \\
\hline Mllk Snake & Lampropeltis trlangulum & Species of Concern & Species of Special Concern & & & & & $x$ & \\
\hline Gopher Snake Or Bullsnake & Pituophis catenifer & & & & & & & $x$ & \\
\hline
\end{tabular}


MT Status

\begin{tabular}{|l|l}
\hline MT Status & WY status \\
\hline
\end{tabular}

Thamnophis elegan

Thamnophis radix

lains Garter Snak Garter Snake

Common Garter Sng

Thamnophis sirtalis

Crotalus viridis

On Review

Western Rattlesnake

$-$

BLM_STATUS FS STATUS

USESA

\begin{tabular}{l|l|l|}
\hline Confirmed & Probable & Possible \\
\hline
\end{tabular}

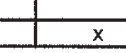


Appendix 3. Plant Species of Concern Documented or Potentially Occurring in the Hanging Woman Basin 
Appendix 3. Plant Species of Concern Documented or Potentially Occurring in the Hanging Woman Basin.

\begin{tabular}{|c|c|c|c|}
\hline \multicolumn{4}{|c|}{$\begin{array}{c}\text { Plant Species of Concern Documented or Potentially Occurring in the Hanging Woman } \\
\text { Basin. }\end{array}$} \\
\hline $\begin{array}{l}\text { Scientific Name } \\
\end{array}$ & Common Name & Global Rank & State Rank \\
\hline Astragalus barrii & Barr's Milkvetch & G3 & $\begin{array}{l}\text { S2S3 (MT) } \\
\text { S3 (WY) }\end{array}$ \\
\hline Carex gravida var. gravida & Pregnant Sedge & G5T5 ? & $\begin{array}{l}\text { S1 (MT) } \\
\text { S2 (WY) }\end{array}$ \\
\hline Ceanothus herbaceous var. pubescens & New Jersey Tea & G5T? & $\mathrm{SH}(\mathrm{MT})$ \\
\hline Cypripedium parviflorum var. pubescens & Large yellow Lady's-slipper & G5 & S1S2 (WY) \\
\hline Dichanthelium oligosnthes var. scribnerianum & Scribner's Panic Grass & G5T5 & \begin{tabular}{|l|} 
S1 (MT) \\
S3 (WY)
\end{tabular} \\
\hline Eragrostis hypnoides & Teal Love Grass & G5 & S1 (WY) \\
\hline Eupatorium maculatum var. bruneri & Joe-pye Weed & G5T4T5Q & $\begin{array}{l}\text { S2 (MT) } \\
\text { S2 (WY) }\end{array}$ \\
\hline Lomatium nuttallii & Nuttall's Desert-parsley & G3 & \begin{tabular}{|l|} 
S1 (MT) \\
S3 (WY) \\
\end{tabular} \\
\hline Musineon vaginatum & Sheathed Musineon & G3G4 & \begin{tabular}{|l|} 
S3 (MY) \\
S2 (WY) \\
\end{tabular} \\
\hline Nothocalais troximoides & False Agoseris & G5 & S1 (WY) \\
\hline Pedicularis contorta var. ctenophora & Coil-beaked Lousewort & G3T3 & S2 (WY) \\
\hline Physaria brassicoides & Rydberg Double Twinpod & G5 & \begin{tabular}{|l|} 
S2 (MT) \\
S3 (WY)
\end{tabular} \\
\hline Physaria didymocarpa var. lanata & Woolly Twinpod & G5T2 & \begin{tabular}{|l|} 
S1 (MT) \\
S2 (WY) \\
\end{tabular} \\
\hline Polygonum spergulariiforme & Fall Knotweed & G5T4 ? & S1 (WY) \\
\hline Schoenoplectus heterochaetus & Slender Bulrush & G5 & \begin{tabular}{|l|} 
S1 (MY) \\
S1 (WY) \\
\end{tabular} \\
\hline Sparganium eurycarpum & Large Bur-reed & G5 & S1 (WY) \\
\hline Sullivantia hapemanii var. hapemanii & Hapeman's Sullivantia & G3T3 & $\begin{array}{l}\text { S2 (MT) } \\
\text { S3 (WY) }\end{array}$ \\
\hline Symphyotrichum mollis & Soft aster & G3 & S3 (WY) \\
\hline Triodanis leptocarpa & Slim-pod Venus' Looking-glass & G5? & S1 (WY) \\
\hline Viburnum lentago & Nannyberry & G5 & $\begin{array}{l}\text { S1 (MT) } \\
\text { S2 (WY) }\end{array}$ \\
\hline
\end{tabular}


Appendix 4. Potential Plant Associations 
Appendix 4. Plant Associations with potential to be located on Forks Ranch Unit, Padlock Ranch.

\begin{tabular}{|c|c|c|}
\hline \multicolumn{3}{|c|}{ Plant Associations with potential to be located on Forks Ranch Unit, Padlock Ranch * } \\
\hline \begin{tabular}{|l|} 
Plant Association Name \\
\end{tabular} & G-Rank & S-Rank \\
\hline Acer negundo / Prunus virginiana Forest & G3 & G3 \\
\hline Artemisia cana / Pascopyrum smithii Shrubland & G4 & S4 \\
\hline Artemisia cana ssp. cana / Pascopyrum smithii Shrub Herbaceous Vegetation & G4 & S3? \\
\hline Artemisia tridentata ssp. tridentata / Pascopyrum smithii - (Elymus lanceolatus) Shrubland & G3? & S3 \\
\hline Artemisia tridentata ssp. wyomingensis - Atriplex confertifolia Shrubland & G3G5 & S3 \\
\hline Artemisia tridentata ssp. wyomingensis / Hesperostipa comata Shrubland & G2 & not recorded \\
\hline Artemisia tridentata ssp. wyomingensis / Mixed Grasses Shrub Herbaceous Vegetation & G5 & not recorded \\
\hline Artemisia tridentata ssp. wyomingensis / Pascopyrum smithii Shrubland & G4 & S? \\
\hline Artemisia tridentata ssp. wyomingensis / Pseudoroegneria spicata Shrub Herbaceous Vegetation & G4 & S3 \\
\hline Calamovilfa longifolia - Hesperostipa comata Herbaceous Vegetation & G3 & S3 \\
\hline \multicolumn{3}{|l|}{ Cercocarpus montanus var. ??; (no specifics given for undergrowth!) } \\
\hline Crataegus douglasii - (Crataegus chrysocarpa) Shrubland & G2? & $\mathrm{S} 2$ \\
\hline Festuca idahoensis - Pascopyrum smithii Herbaceous Vegetation & G3 & S? \\
\hline Fraxinus pennsylvanica / Prunus virginiana Forest CEGL000642 & G3? & S2S3 \\
\hline Hesperostipa comata - Bouteloua gracilis - Carex filifolia Herbaceous Vegetation & G 5 & S? \\
\hline Pascopyrum smithii - Bouteloua gracilis Herbaceous Vegetation & G5 & not recorded \\
\hline Pascopyrum smithii - Hesperostipa comata Central Mixedgrass Herbaceous Vegetation & G4 & not recorded \\
\hline Pascopyrum smithii - Nassella viridula Herbaceous Vegetation & G3G4 & S4? \\
\hline Pinus ponderosa / Carex inops ssp. heliophila Woodland & G3G4 & S3S4 \\
\hline Pinus ponderosa / Festuca idahoensis Woodland & G4 & S4 \\
\hline Pinus ponderosa / Mahonia repens Forest & G3Q & \$3 \\
\hline Pinus ponderosa / Prunus virginiana Forest & G3 & S4 \\
\hline Pinus ponderosa/Pseudoroegneria spicata Woodland & G4 & $\$ 4$ \\
\hline Pinus ponderosa / Symphoricarpos occidentalis Forest & G3 & S3 \\
\hline \multicolumn{3}{|l|}{ Populus angustifolia / (no specifics given for undergrowth!) } \\
\hline \multicolumn{3}{|l|}{ Populus deltoides / no specifics given for undergrowth) } \\
\hline Populus deltoides / Pascopyrum smithii Woodland & G3? & WY: S3? \\
\hline Pseudoroegneria spicata - Bouteloua curtipendula Herbaceous Vegetation & G4G5 & S3 \\
\hline Pseudoroegneria spicata - Bouteloua gracilis Herbaceous Vegetation & G4 & S3 \\
\hline Rhus trilobata / Carex filifolia Shrub Herbaceous Vegetation & G3? & S3 \\
\hline Rhus trilobata / Festuca idahoensis Shrub Herbaceous Vegetation & G3 & S3 \\
\hline Rhus trilobata / Pseudoroegneria spicata Shrub Herbaceous Vegetation & G4 & S4 \\
\hline Sarcobatus vermiculatus / Artemisia tridentata Shrubland & G4 & S\$ \\
\hline Sarcobatus vermiculatus / Pascopyrum smithii - (Elymus lanceolatus) Shrub Herbaceous Vegetation & G4 & S4 \\
\hline Sarcobatus vermiculatus / Pseudoroegneria spicata Shrubland & G3 & S3 \\
\hline Schizachyrium scoparium - Carex filifolia & G4 & S3 \\
\hline Spartina pectinata Western Herbaceous Vegetation & G3 & S3 \\
\hline Yucca glauca / Calamovilfa longifolia Shrub Herbaceous Vegetation & G4 & S4 \\
\hline
\end{tabular}

* Probability of occurrence determined from Great Plains Rapid Ecological Assessment (Martin et al. 1998) and Wyoming Natural Diversity Database 